CIRCULATION AND CONTAMINANT TRANSPORT IN

MASSACHUSETTS COASTAL WATERS:

A SUMMARY OF ACHIEVEMENTS AND FUTURE PLANS

work conducted under a

JOINT FUNDING AGREEMENT

between

THE MASSACHUSETTS WATER RESOURCES AUTHORITY and

THE UNITED STATES DEPARTMENT OF INTERIOR

U. S. GEOLOGICAL SURVEY

By

M.H. Bothner, M. Buchholtz ten Brink, Bradford Butman,

H. J. Knebel, F.T. Manheim, and R. P. Signell

U.S. Geological Survey, Woods Hole, MA

U.S. Geological Survey Open File Report \# 94-649 


\section{TABLE OF CONTENTS}

Executive Summary $\ldots \ldots \ldots \ldots \ldots \ldots \ldots \ldots \ldots \ldots \ldots$

Summary of USGS Program Components:

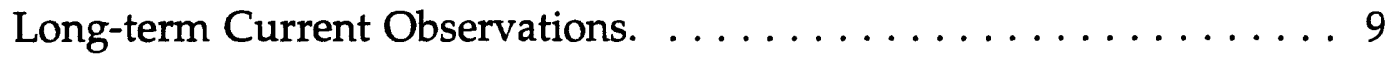

Geochemical Studies $\ldots \ldots \ldots \ldots \ldots \ldots \ldots \ldots \ldots \ldots$

Sea-floor Mapping $\ldots \ldots \ldots \ldots \ldots \ldots \ldots \ldots \ldots \ldots \ldots$

Circulation Modeling $\ldots \ldots \ldots \ldots \ldots \ldots \ldots \ldots \ldots \ldots \ldots$

Contaminated-Sediment Database $\ldots \ldots \ldots \ldots \ldots \ldots \ldots \ldots \ldots$

References cited in this summary $\ldots \ldots \ldots \ldots \ldots \ldots \ldots \ldots \ldots \ldots$

Publications resulting from the MWRA-USGS

Joint Funding Agreement and related USGS programs

in Boston Harbor and Massachusetts Bay 1989-1994 . . . . . . . . . . 36

This report has not been reviewed for conformity with USGS editorial standards. Any use of trade, product, or firm names is for descriptive purposes only and does not imply endorsement by the U.S. Government. 


\section{EXECUTIVE SUMMARY}

The USGS is developing a conceptual model for the transport and accumulation of sediments and associated contaminants in the Massachusetts Bays. Our approach is multidisciplinary. Each of five discipline activities is designed to add new information, which builds and tests the conceptual model. Our overall objective is to provide a predictive capability of the fate of contaminants associated with fine-grained sediments. We emphasize sediments because most contaminants introduced to the ocean are adsorbed by and transported with suspended sediments. After complicated cycles of deposition, resuspension, and biological and chemical interactions, contaminants on particles may be eventually buried in bottom sediments, which become the ultimate contaminant sink. Our research addresses the fundamental questions of how and when contaminants are transported and where in Massachusetts Bays will they accumulate. Knowledge about the fate of contaminants introduced to Massachusetts coastal waters is of paramount importance to the Massachusetts Water Resources Authority (MWRA). This state agency is responsible for a $\$ 4$ billion upgrade to Boston's sewage treatment facility and for a program to monitor effluent effects on the coastal environment. Results of our research are also sought by environmental managers, engineers, scientists, regulatory agencies, politicians, and the public.

Each of the five components of our program, listed below, contributes to the conceptual model of the fate and transport of contaminants. Their research continues to answer practical questions of concern to MWRA, with whom the USGS has formulated a Joint Funding Agreement to carry out this work during the period 19891997.

1. The long-term current observations address the question, "How are sediments transported from the new outfall site?" USGS has maintained a monitoring station near the future outfall site continuously since 1989 (Fig.1). These are the only time-series measurements of water properties in Massachusetts Bay and the continuous observations fill the gaps in the MWRA Outfall Monitoring Program shipboard surveys which occur at approximately bi-monthly intervals. The USGS measurements allow comparison of conditions between different seasons and years and also characterize the rare, high-energy events such as major storms that are the principal cause of sediment redistribution. Near-bottom currents during storms typically transport material offshore toward Stellwagen Basin and southeastward toward Cape Cod Bay. This data set is also used to validate computer models of regional current flow that form the basis of MWRA's water quality model. In addition, the long-term mooring will provide direct observations during the plumetracking studies once the new outfall is on line.

2. Sediment contamination studies are answering the questions, "What are the concentrations of pollutants in western Massachusetts Bay and how have they changed with time?" These studies compare the present concentrations and inventories of contaminants in locations of the harbor and bay where sediments are likely to accumulate with past and pre-industrial levels. They provide baselines 


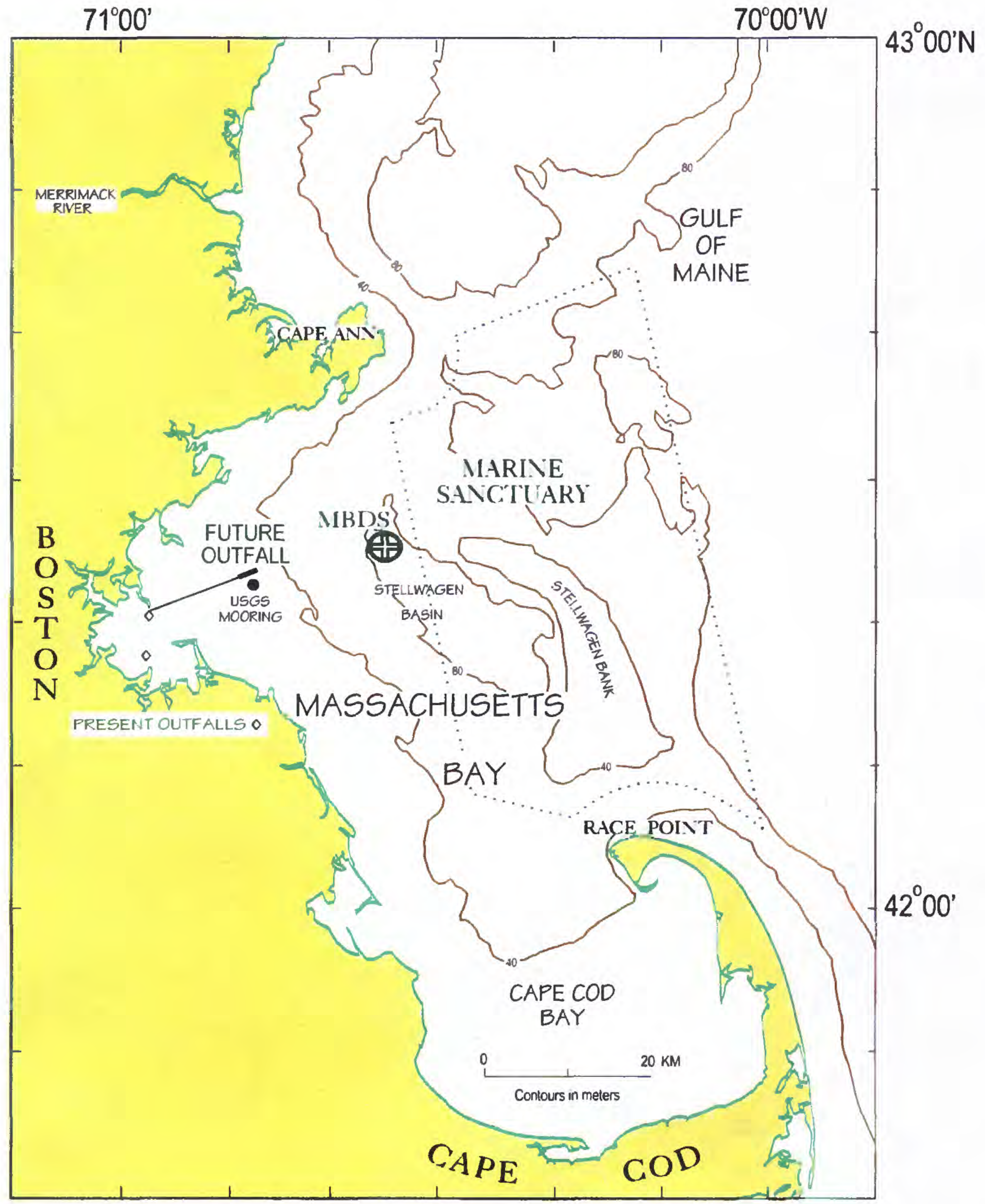

Figure 1. This map shows the locations of present and future outfalls for discharging treated sewage effluent in coastal waters off Boston, Massachusetts. The USGS mooring has been collecting data continuously since December 1989 near the future outfall location. The Massachusetts Bay Disposal Site (MBDS), in Stellwagen Basin, has received a variety of wastes in the past, but now receives only clean dredge spoils. To the east of the dumpsite is the Stellwagen Bank National Marine Sanctuary. 
against which possible changes related to the new outfall or other new sources can be measured. Documenting the range of natural changes in the baseline is essential in order to interpret the cause of any changes that occur after new sources are brought on line. For example, the 5 year time-series of sediment analyses near the future outfall documented a 2-fold increase in concentrations of silver and Clostridium perfringens (both tracers of sewage particles) beginning in winter of 1992 and lasting for about 1 year (see p. 15). The increase occurred after the exceptionally strong storm of mid December 1992 and we hypothesize that contaminated sediments in the harbor were resuspended and flushed offshore during this event. The long-term baseline, with knowledge of natural variability, is essential when assigning a cause to a measured environmental change.

3. Sea-floor mapping has addressed the question, "What are the best locations for sampling to monitor changes in contaminants on a regional basis?" Mapping of the seafloor has been completed in Boston Harbor and Massachusetts Bay, and areas of sediment erosion and sediment deposition have been identified. Mapping is continuing in Cape Cod Bay as well as on Stellwagen Bank (under separate funding) to provide a complete regional understanding of the sea-floor environment. The maps provide a long-term perspective to the conceptual model of sediment transport and deposition, and they complement the short term measurements of currents. These unique maps of sedimentary environments also provide information on distribution and size of habitats for sea-floor organisms. These maps also define regions of similar sediment types and allow extrapolation of sea-floor ecology and contaminant inventories to a bay-wide scale based on limited sampling.

4. Circulation modeling provides the capability to address the question, "How are nutrients, sediments, contaminants and other water-borne materials transported in Massachusetts and Cape Cod Bays?" The three-dimensional computer model implemented by USGS: explains the mechanism for the observed mean counterclockwise circulation in Massachusetts Bay, has been used to determine how quickly material is flushed from the system, and is the basis for the MWRA waterquality model. The model has been used to compare the existing and new outfall sites with respect to dilution of effluent by physical processes and the results were used by the U.S. Justice Department in the case concerning endangered species. In addition, a video showing the three dimensional model results has been widely shown at public forums and has contributed significantly to public education.

Over the next three years, the USGS will continue to develop the circulation model, adding a sediment transport component. This model will contribute to and be tested by the results of: long-term current observations, geologic mapping, geochemistry, and syntheses from the contaminated-sediments database. When the new outfall comes on line, computer simulations will be carried out as part of the MWRA plume-tracking studies.

Under separate funding, the circulation modeling is being used to understand the transport mechanisms and distribution of the red tide organism Alexandrium tamarense in the western Gulf of Maine, and the processes by which cells are 
transported into Massachusetts Bay.

5. Contaminated-sediment database development seeks to answer the question, "What is the distribution of contaminants in harbor sediments that are at concentrations having potential toxic effects, and are the concentrations decreasing with time in response to MWRA's harbor cleanup program?" Of the 12 heavy metals investigated so far, 6 are of environmental concern. The long-term compilation suggests a decrease in concentration over time in the surface sediment of the inner harbor (see p. 32). Data on organic contaminants are presently being compiled and validated.

Use of the database with visualization applications has been an integral component of the USGS research program in Boston Harbor and the Massachusetts Bays, although it has not been funded until now through the MWRA-USGS Joint Funding Agreement. Major achievements of this effort have included: creation of a comprehensive contaminated sediment data dictionary; collection of data on more than 2500 samples from historical sources; and development of new approaches in validating data and converting data to formats useable on most desktop computers.

\section{Continuing and Future Work}

The present Joint Funding Agreement (1994-1997) will allow USGS and MWRA to continue to cooperatively address issues of critical concern to both agencies in the Massachusetts Bays. Based on the understanding of the Massachusetts Bays system developed over the last 5 years, the USGS and the MWRA are now in a unique position to:

* Assess the magnitude of contaminant changes in the bottom sediments that result from the new outfall and from continued efforts at reduction of contaminants at the source

* Provide direct measurements of currents and computer simulations of the effluent plume during the post-operational phase of the outfall monitoring program

* Provide long-term observations of currents to assess annual and interannual variability and to document major events that are essential to the interpretation of changes documented once the outfall comes on line

* Complete development of the conceptual sediment transport model for the Massachusetts Bays that will continue to provide a framework for management decisions and understanding of the sediment transport system.

Tables 1 and 2 summarize the history of studies completed and the schedule of continuing and future work. 


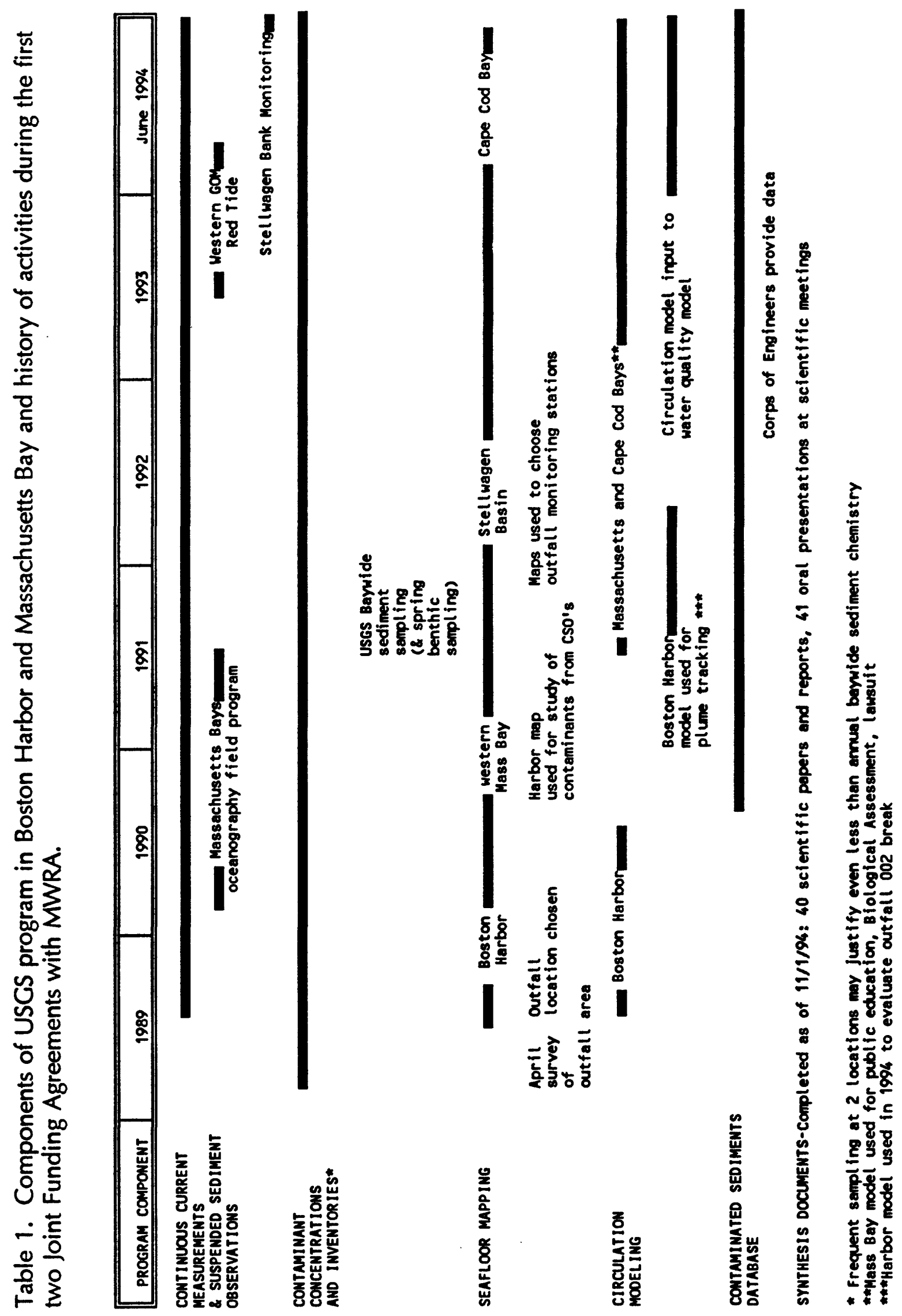




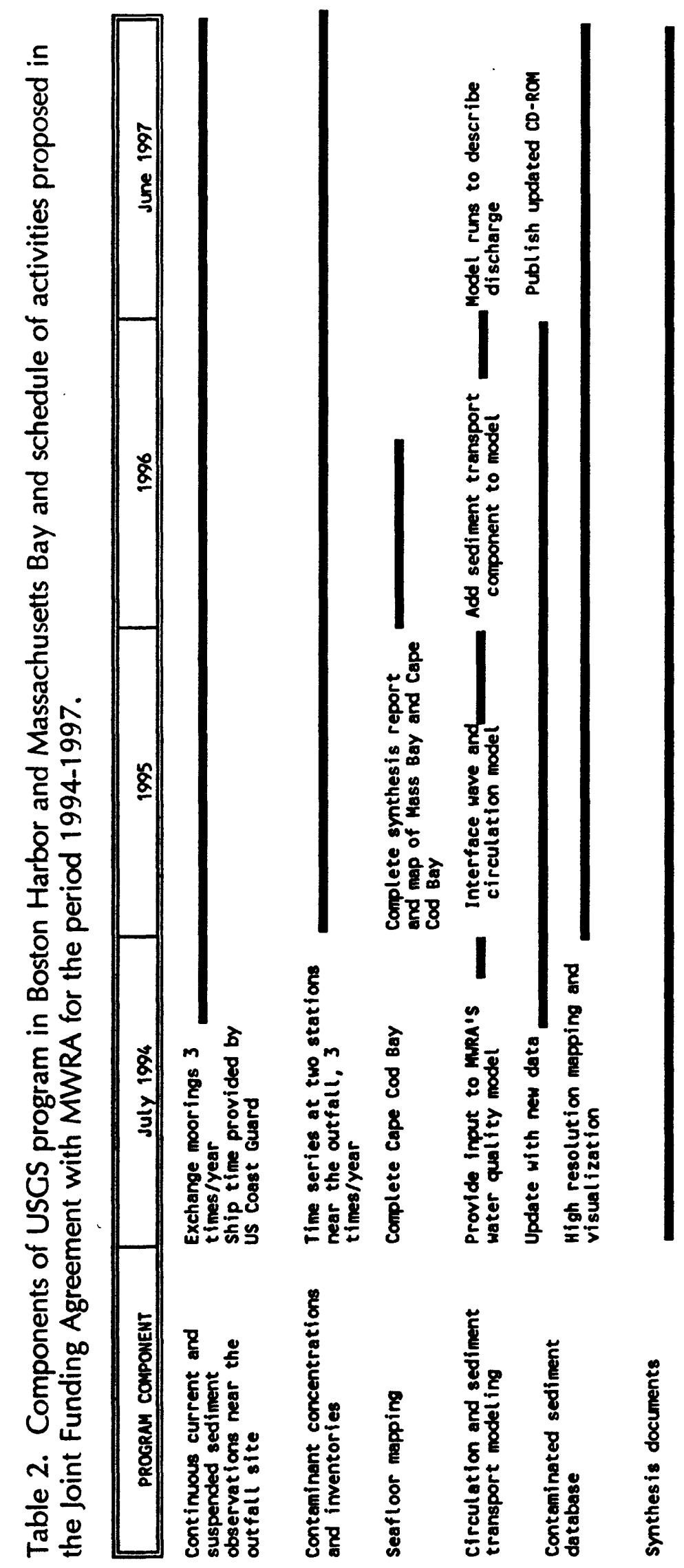




\section{LONG-TERM CURRENT AND SEDIMENT TRANSPORT OBSERVATIONS}

To determine the fate of contaminants discharged at the outfall site, we need to understand both how material in the water column is transported away from the site and how material that settles to the bottom of Massachusetts Bay is resuspended. The USGS is obtaining long-term data to address these issues. We have been measuring currents, suspended sediments, temperature, salinity and dissolved oxygen at the new outfall site since December 1989.

\section{Goals and Achievements}

1. Determine seasonal and interannual variability of currents, water properties and suspended matter in western Massachusetts Bay.

* Mean currents at the new outfall site are weak compared to fluctuations. This means the plume from the new outfall will not initially have a preferred direction as it leaves the outfall area.

* Our measurements show that during both winter and summer, current fluctuations will typically carry effluent from the new outfall about $3-5 \mathrm{~km}$ in one day.

* Although surface current fluctuations during the summer increase significantly, the plume is expected to be trapped in the lower layer where current fluctuations are comparable to winter.

* The seasonal variation in the current statistics is similar from year to year. This suggests that calculations based on the current statistics can be computed with one year's data and be relevant to other years.

* The time-series sediment traps show that sediment flux to the trap is at maximum in spring, a minimum in summer, and increases in late summer and fall. The flux in winter is highly variable. Understanding the timing and causes of this seasonal trend is important because many of the same processes control the distribution of contaminants that are associated with fine-grained sediments.

2. Determine the factors controlling sediment resuspension in western Massachusetts Bay.

* Time-series sediment traps and turbidity measurements at the USGS mooring location (Fig.1) show that sediment resuspension is dominated by winter storm events (Fig.2). Material is resuspended to at least within $5 \mathrm{~m}$ (15 feet) from the surface during these events, providing an opportunity for suspended matter to adsorb dissolved pollutants from the seawater over most of the water column (30 $\mathrm{m}$ or 100 feet water depth) at this location. 


\section{Sediment Trap Bottles}
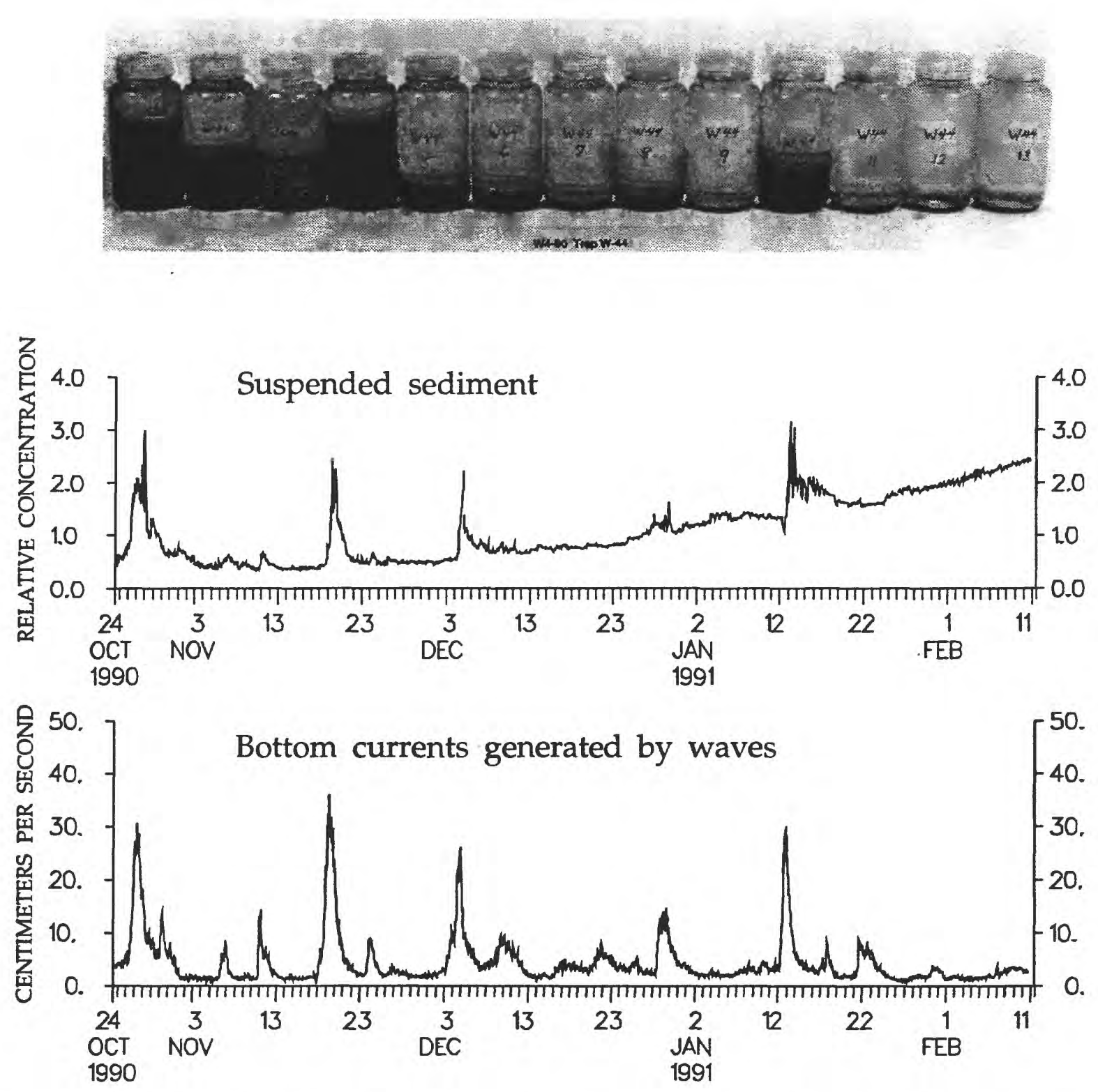

Figure 2. (Top) Sample bottles from a time-series sediment trap located 4 meters (13 feet) above the bottom near the future outfall location. Each bottle represents accumulations during a 9-day interval between October 1990 and February 1991. (Middle) Suspended sediment concentration based on light transmission shows peaks in turbidity that correlate well with sample bottles. (The upward trend beginning in December was caused by algae fouling the lenses of the turbidity sensor.) (Bottom) There is a clear correlation between the four most intense periods of wave activity and the peaks in suspended sediment shown by the upper graph and the bottles. This correlation indicates that waves are the major cause of resuspension. The samples in bottles are also used to measure suspended sediment attributes (such as texture and contaminant concentrations) during stormy and calm periods. 
* The sediment resuspension events are usually accompanied by strong winds from the northeast. Current meter measurements show that the surface currents driven by these winds are toward Cape Cod Bay, while currents near the bottom veer more toward Stellwagen Basin and Cape Cod Bay (Fig. 3). Storms are therefore expected to carry sediment from western Massachusetts Bay to the south and southeast, away from Boston Harbor.

3. Provide measurements of currents and time-series water properties for MWRA monitoring program and for verification of the water quality models.

* $\quad$ Since spring of 1991, the USGS long-term mooring has provided the only measurement of currents in Massachusetts Bay, and the only time-series measurements of water properties. The time-series data fill in the gaps in the MWRA Monitoring Program shipboard surveys, which measure properties with high spatial resolution, but at only monthly or longer intervals.

* Data collected provides verification information for the water quality modeling. The water quality model has focused on 1992, since that marks the first year of bay-wide nutrient information obtained by the Outfall Monitoring Program. Without the currents measured at the long-term mooring, there would have been no verification of model predicted currents for this period.

\section{Continuing and Future Work}

The mooring will continue to provide information for the Outfall Monitoring Program and for the water quality model. When the outfall comes on line, these measurements will also allow interpretation of plume-tracking studies and provide necessary stratification and current data for calibrating and verifying initial mixing models. In anticipation of the outfall coming on line, the mooring has recently been outfitted with an acoustic current profiler that can resolve the vertical structure of the currents at $1 \mathrm{~m}$ intervals. This will be important for interpreting the transport and mixing of the effluent during summer months because the plume will rise to the region near where currents can change dramatically with depth. 


\section{Storm Response at Future Outfall Site}

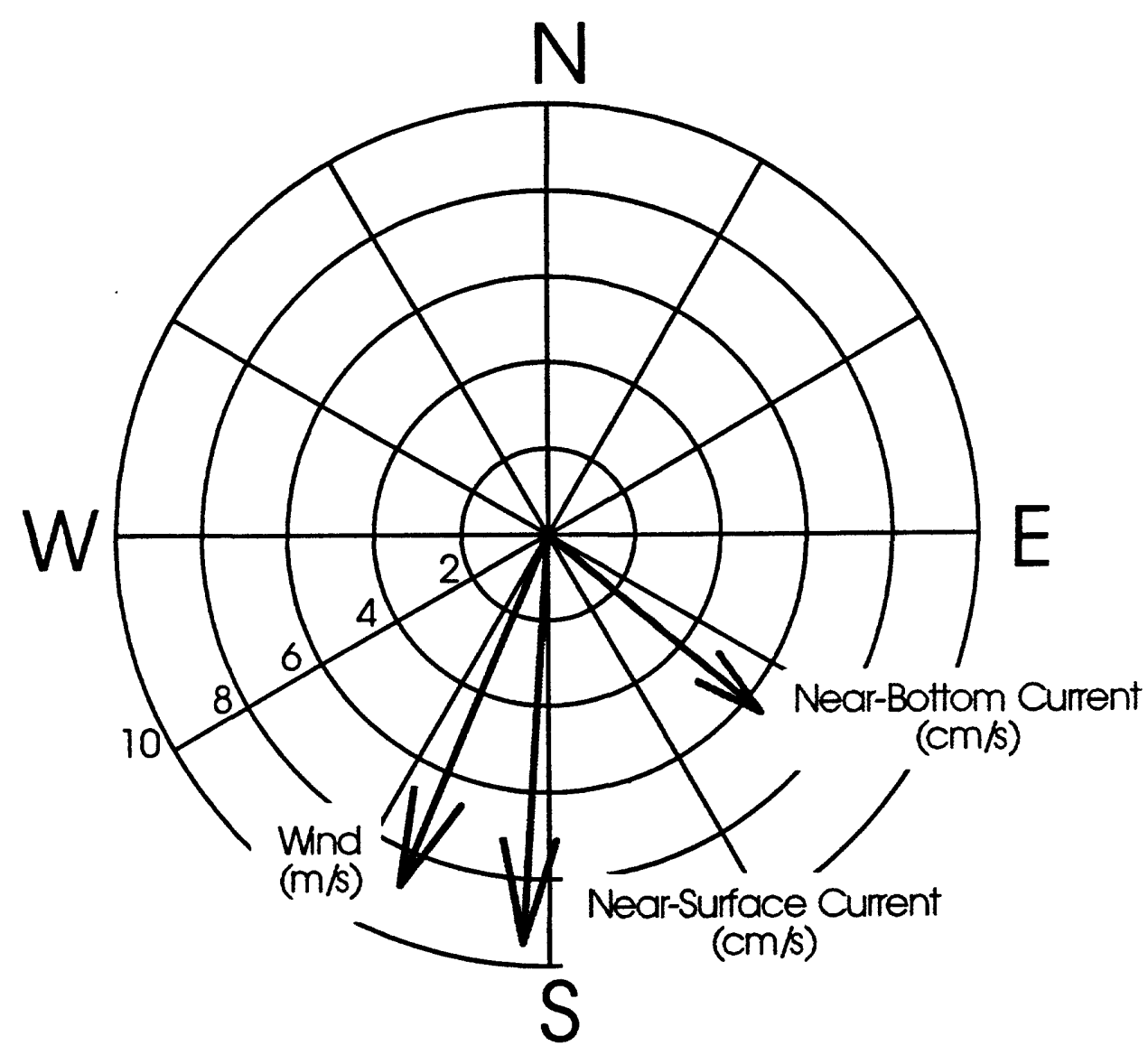

Figure 3. Mean wind and currents occurring at the future outfall site (Fig. 1) during strong resuspension events (wave heights greater than $3 \mathrm{~m}$ ). Northeasterly winds drive near-surface currents to the south toward Cape Cod Bay and near-bottom currents to the southeast toward Stellwagen Basin and Cape Cod Bay. 


\section{GEOCHEMICAL STUDIES}

The USGS has measured contaminants in sediment cores throughout Massachusetts and Cape Cod Bays and has monitored contaminants in surface sediments at locations near the planned outfall in Massachusetts Bay since 1990. The purpose of this work is to determine the inventories of contaminants and the natural processes affecting their fate and transport. A well documented baseline of contaminant levels, including information on the seasonal and spatial variability, and processes responsible for this variability, will be essential to evaluate any future changes related to the new ocean outfall and other activities.

Silver is a key element in tracking the distribution of sludge derived particles. Because of its use in photography, sewage particles contain silver at concentrations often 1000 times higher than background levels in sediments. Steps to reduce toxic waste discharges at the source have significantly reduced the discharge of silver in sewage effluent since the mid 1980s, but past discharges have resulted in high concentrations of silver in sediments of the harbor and bay (Fig. 4).

The concentration of silver, normalized by sediment grain size, generally decreases with distance seaward from the mouth of Boston Harbor. However the silver concentrations, and inventories are anomalously high in Cape Cod Bay. As there are no known local sources of silver, these data suggest preferential deposition in Cape Cod Bay of sewage particles that were discharged in Boston Harbor. This process may be facilitated by currents which often travel in a southerly direction along the southwestern shore of Massachusetts Bay toward Cape Cod Bay. A new technique of tracing sewage particles which utilizes differences in the isotopic ratios of the element osmium, an element used in biochemical research, will be used to test the hypothesis that Boston sewage is indeed the source of silver contamination in Cape Cod Bay.

\section{Long-term monitoring shows an increase in silver near the future outfall} possibly in response to a major storm. On fifteen occasions at approximately 4 month intervals since spring 1989, the USGS has collected cores from one location in Massachusetts Bay (Station 3, Fig. 4) The analysis of silver and the sludge tracer, Clostridium perfringens, shows low variability through mid-October, 1992 and a significant increase by the February 1993 cruise (Fig. 5 and 6). A possible explanation for this increase is transport and deposition of mud from Boston Harbor to Massachusetts Bay as a result of an unusually violent storm on December 11-16, 1992 when waves reached $8 \mathrm{~m}$ ( $26 \mathrm{feet})$ in height at the future outfall site (Fig. 7). Longterm data documenting the natural variability is critical prior to evaluating environmental change potentially caused by the new outfall. 


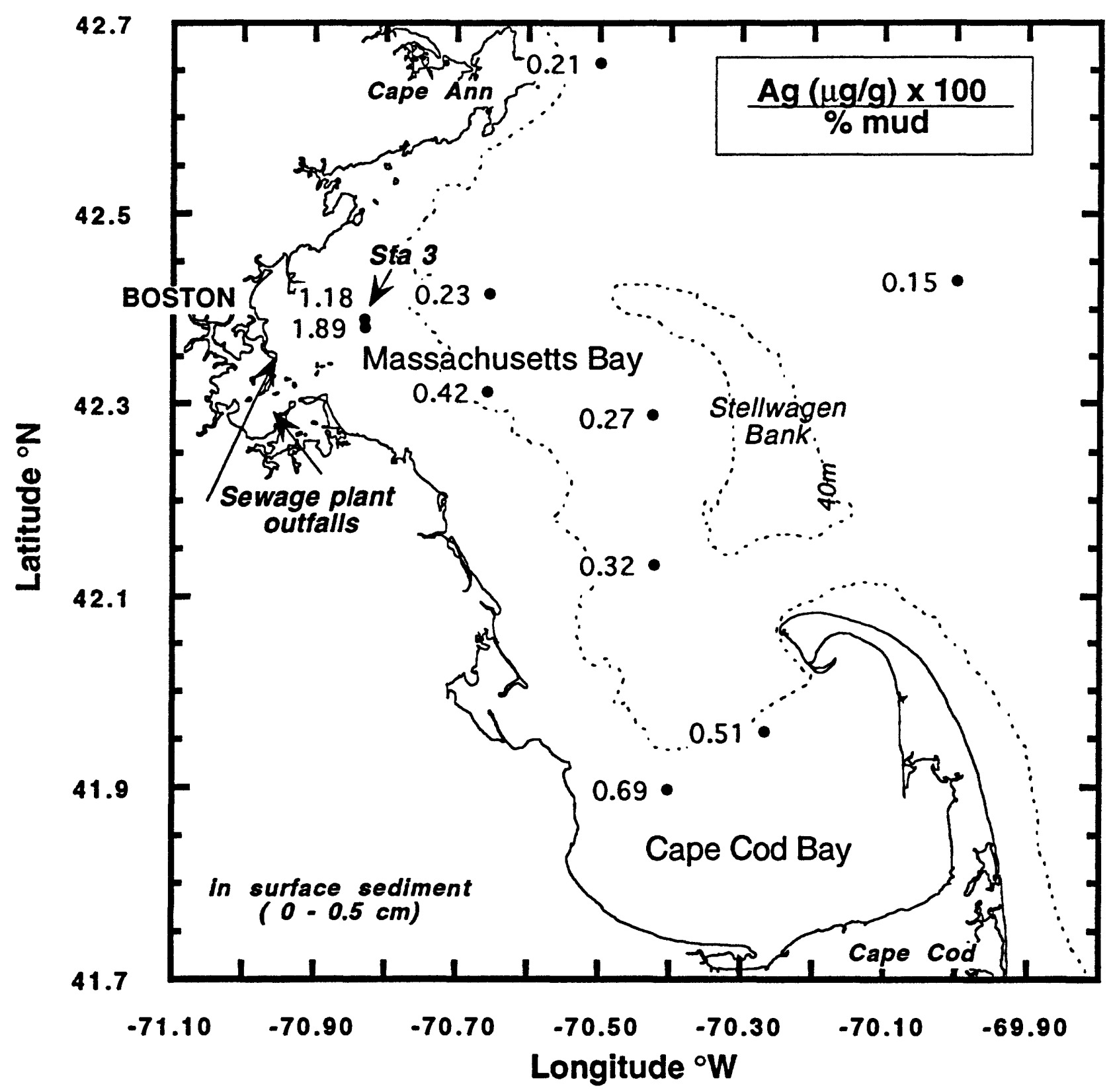

Figure 4 . The concentration of silver (normalized by $\%$ mud) in surface $(0-0.5 \mathrm{~cm})$ sediments collected at 10 locations with a hydraulically damped gravity corer. 


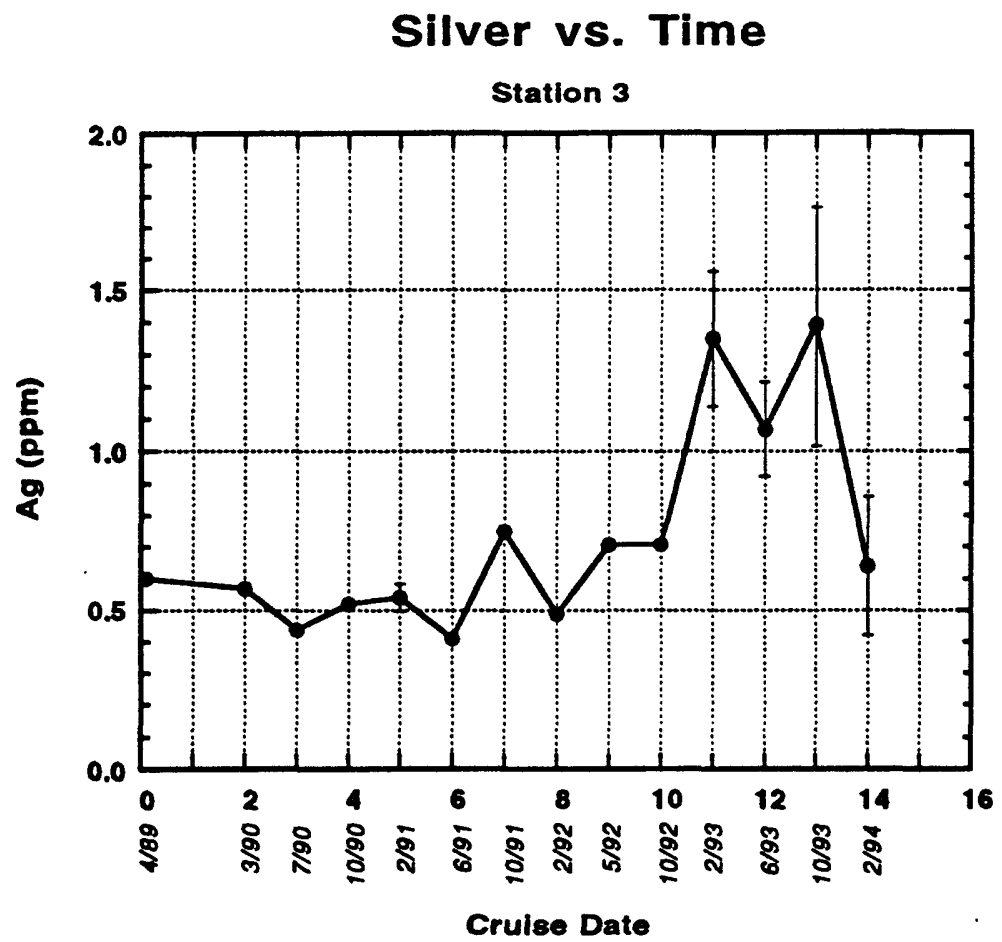

Figure 5. Preliminary data on the concentrations of silver with time in the $0.5-1 \mathrm{~cm}$ layer of sediment at station 3 (Fig.4) in Massachusetts Bay. Error bars represent one standard deviation $(n=3)$. The increase after cruise 10 may be related to accumulation of fine material following the major Northeast storm of December 11-16, 1992.

\section{C. perfringens vs. Time}

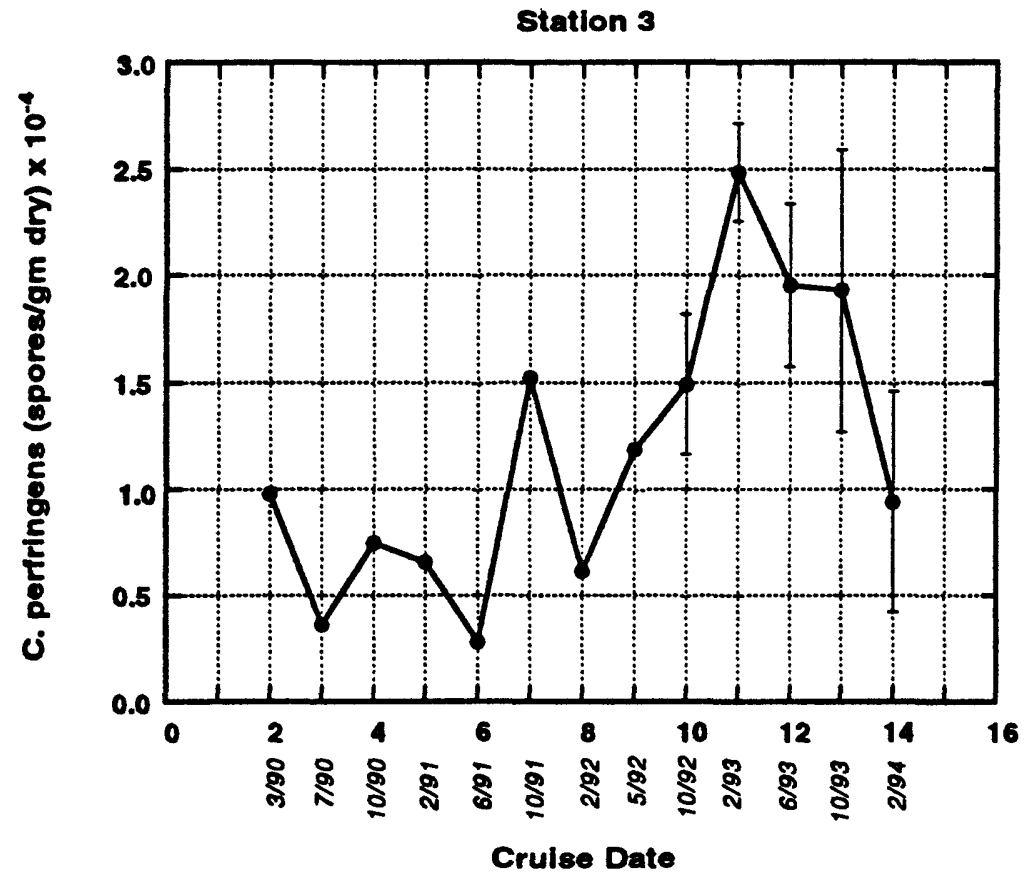

Figure 6. Concentrations of the bacterium spore, Clostridium perfringens, with time in surface sediments of station 3 (Fig. 4) in Massachusetts Bay. Error bars represent one standard deviation $(n=3)$. 


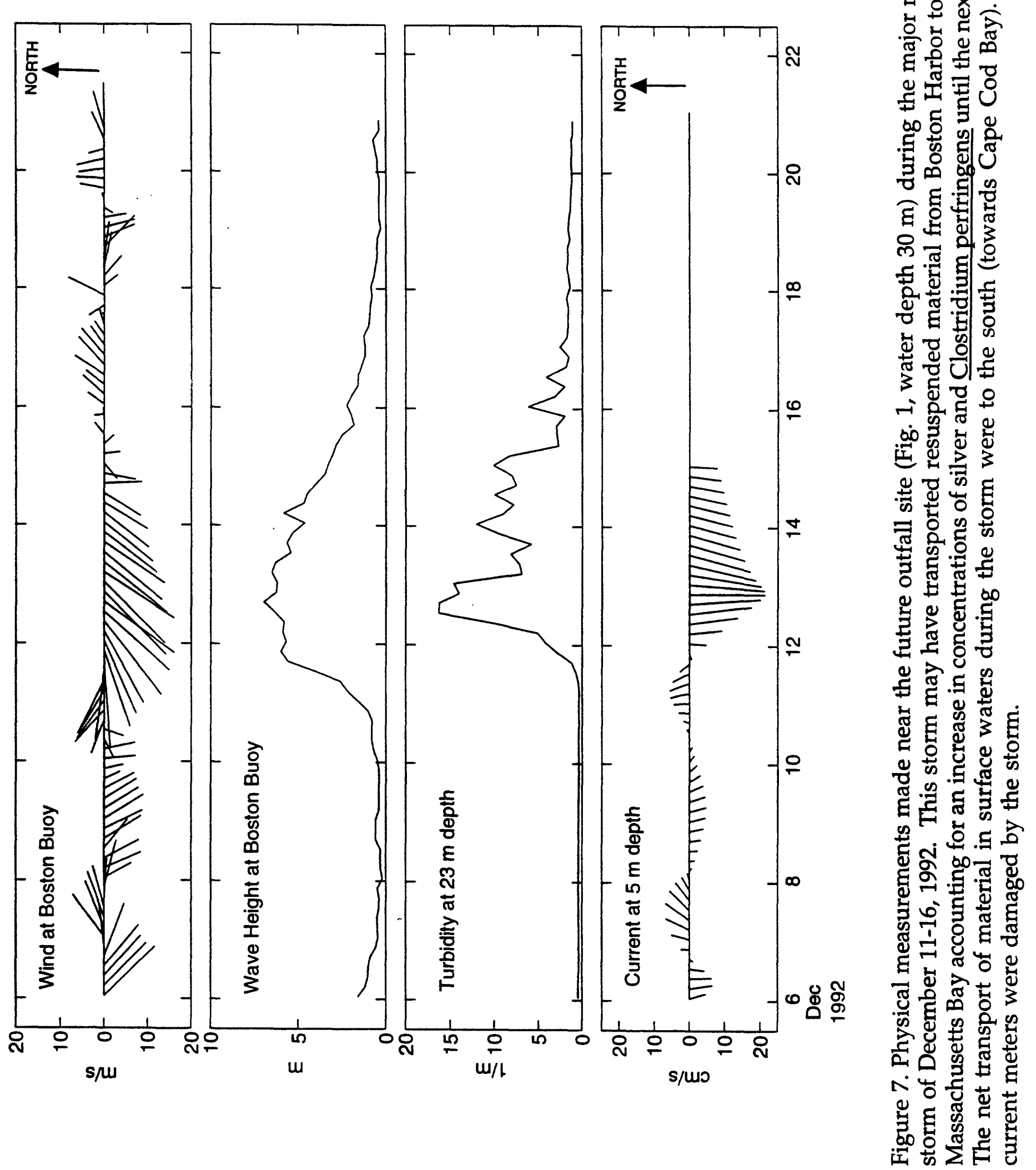


There are other significant facts derived from geochemical analysis of sediment cores from Massachusetts and Cape Cod Bays. (1) In the surface sediment $(0-0.5 \mathrm{~cm})$ at 10 offshore locations, there is a linear correlation between the concentrations of silver and spores from the bacterium Clostridium perfringens, a biological indicator of sewage particles. (2) There is also a strong correlation between silver and mercury suggesting that mercury, a pollutant of concern in harbor sediments, may also be a tracer of sewage in Massachusetts Bay. (3) Sediment-depth profiles of $\mathrm{Pb} 210$, a radioactive element having a predominantly atmospheric source, in conjunction with profiles of silver and other variables, suggests that the sediments from the Bays are well mixed by burrowing organisms. The process of biological mixing will dilute newly added contaminants and in some cases help bury the contaminants to depths that are not reached by processes of resuspension and transport.

\section{Continuing and Future Work}

Monitoring sediment contaminant levels near the future outfall site will continue the baseline against which future discharge-related changes can be compared to natural variability. Evaluation of post-discharge contaminant inventories are also proposed at a far-field depositional site and a control site at annual intervals after the new outfall is on line. The synthesis of data on metals, radioisotopes, organic contaminants (determined under contract with Massachusetts Bays Program), and physical properties of sediment will provide a current assessment of pollution levels in bay sediments and new insights into processes which control the accumulation and fate of contaminants entering the bays from any new sources. 


\section{Results to Date}

Over the past five years, the modern sea-floor sedimentary environments within the glaciated, topographically complex Boston Harbor and Massachusetts Bay area have been interpreted and mapped from an extensive collection of sidescan sonar records and supplemental marine geologic data. These data outline three categories of sedimentary environments that reflect the predominant long-term processes of erosion, deposition, and sediment reworking. (1) Environments of erosion or nondeposition comprise exposures of bedrock, glacial drift, and coarse lag deposits that contain sediments ranging from boulder fields to gravelly sands and occur in areas of high energy. (2) Environments of deposition are blanketed by muddy sands and muds that have accumulated under predominantly weak bottom currents. (3) Environments of sediment reworking have diverse grain sizes ranging from sandy gravels to muds and are the result of a combination of erosion and deposition.

The distribution of sedimentary environments across the Boston HarborMassachusetts Bay area is extremely patchy (Fig. 8). In local areas, this patchiness reflects the interaction between the irregular bottom topography and the ambient sediment transport processes. Regionally, however, it is governed by differences in geologic and oceanographic conditions among the estuarine, inner shelf, and deep basin parts of the sedimentary system (Fig. 9). The estuarine part of the system (Boston Harbor) is an effective depositional trap for fine-grained detritus because of its protected nature, low wave climate, and relatively large supply of natural and manmade sediments. The inner shelf, on the other hand, is largely mantled by winnowed and sorted sediments due to sediment resuspension and transport especially by storm waves and to a limited supply of sediments that cannot offset losses due to episodic erosion and transport. The deepest part of the system (Stellwagen Basin) is predominantly a tranquil depositional environment in which fine-grained sediments settle through the water column and accumulate on the bottom.

\section{Continuing and Future Work}

During the next two years, under separate funding, the reconnaissance mapping of sedimentary environments will be extended southward to encompass Cape Cod Bay. Because Cape Cod Bay has been shown to be a preferred sink for sewage indicators, it is essential to obtain a regional perspective of the locations there where fine-grained sediments and related contaminants are likely to accumulate. Mapping of the sedimentary environments in Cape Cod Bay will utilize a regional set of high-resolution sidescan sonographs collected along $445 \mathrm{~km}$ of tracklines in June 1994 (Fig. 10). The regional distribution of sedimentary environments in Cape Cod Bay will be inferred from the backscatter patterns in the sonograph records which will be interpreted using the detailed regional bathymetry, the USGS sediment textural data base, the information from a grid of previously collected subbottom 


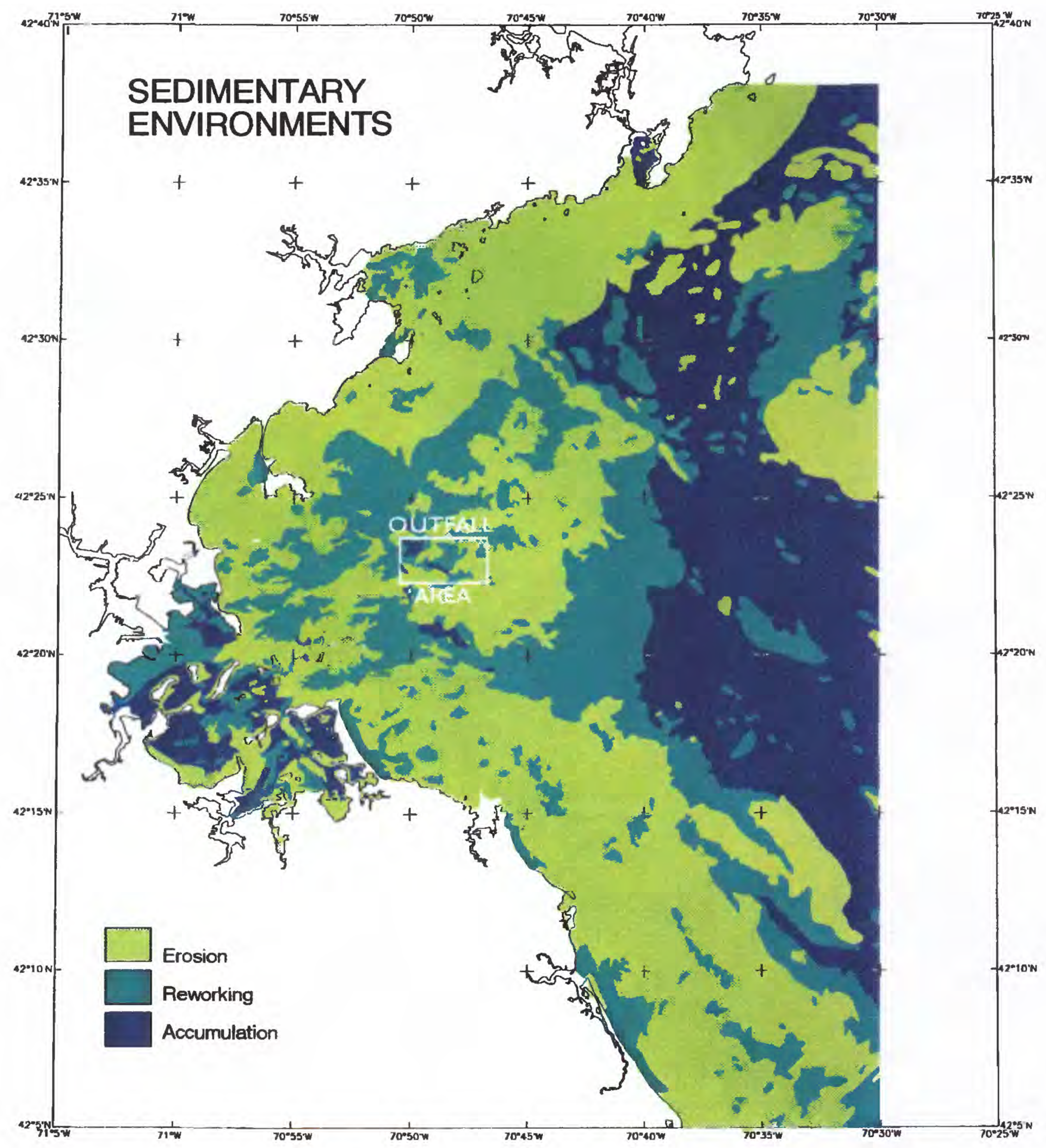

Figure 8. Distribution of environments of sediment erosion, reworking and accumulation across the Boston Harbor-Massachusetts Bay area. 


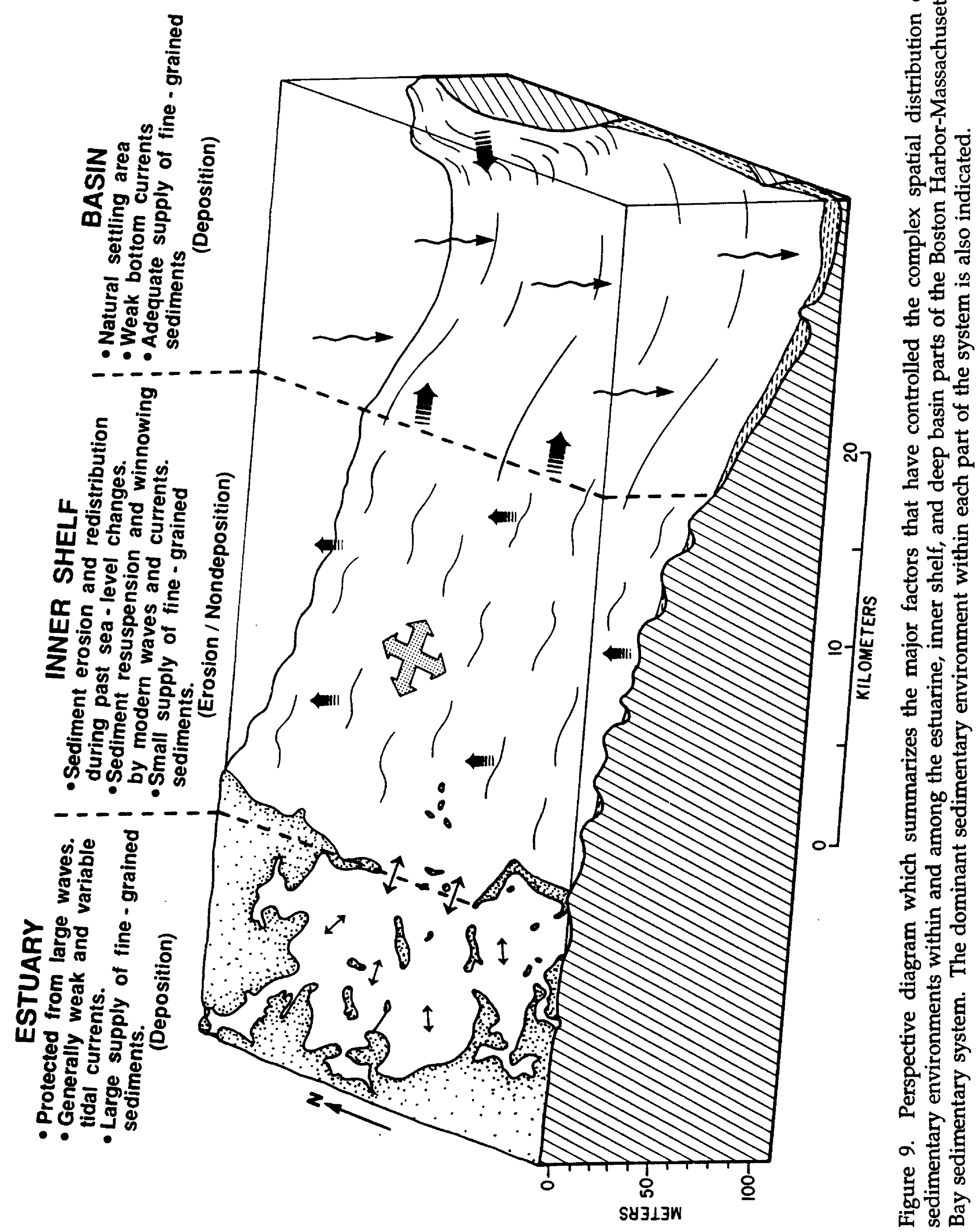


CAPE COD BAY

\section{ASTR94-3}

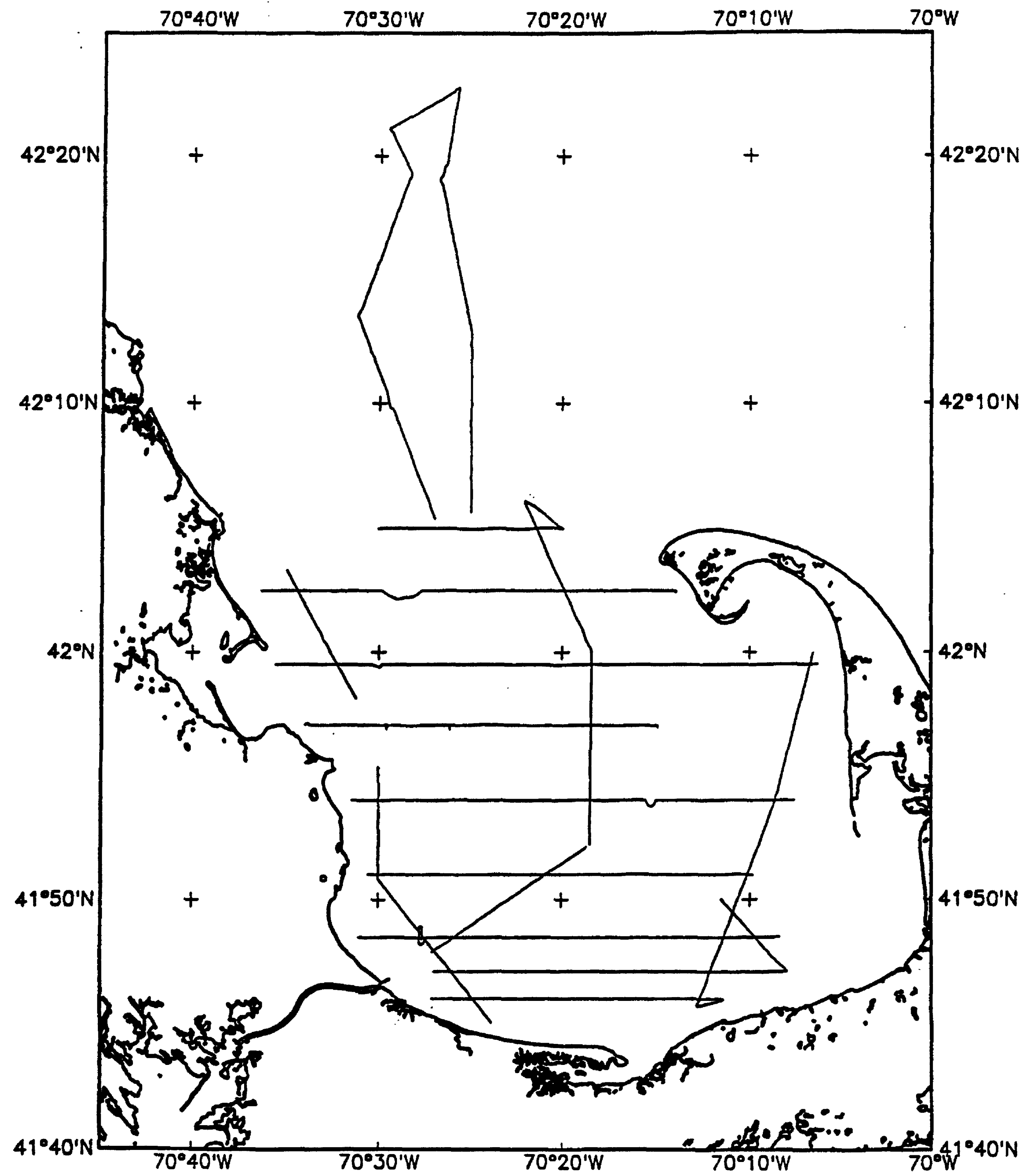

Figure 10. Map of Cape Cod Bay showing tracklines along which high-resolution sidescan sonar records were collected in June 1994. Interpretation of the backscatter patterns in the sonographs will provide the basis for mapping the distribution of bottom sedimentary environments in Cape Cod Bay and for completing a regional reconnaissance map that will extend from Cape Ann on the north to Cape Cod on the south. 
profiles, and more than 70 new sediment samples collected along the sidescan sonar tracklines.

Once the distribution of sedimentary environments has been mapped within Cape Cod Bay, interpretations will be made concerning the geologic and oceanographic conditions that have produced the distribution. The maps and inferences from Cape Cod Bay will then become part of a regional synthesis map of bottom environments that will extend from Cape Ann on the north to Cape Cod on the south, a distance of more than $100 \mathrm{~km}$.

\section{Implications of the Regional Synthesis of Sedimentary Environments}

The regional maps showing the distribution of bottom sedimentary environments across the Boston Harbor-Massachusetts Bay-Cape Cod Bay area are unique in that they outline the distribution of bottom processes rather than sediment types and they are the first ever to encompass an entire nearshore sedimentary system including an estuary, inner shelf area, and deep depositional basins. These maps indicate not only where fine-grained sediments and related contaminants are likely to be either moved or deposited, but they are being used as guides to select sites at which to measure the inventories of contaminants in the sediments or to monitor the changes in contaminant levels with time. In addition, these maps can be used to: (1) explain any observed spatial variations in contaminant concentrations; (2) determine the total inventories of contaminants in the system by highlighting similar areas that might be characterized by only a few sample points; and (3) provide an estimate of the total mass of fine-grained sediments in the system to be used in calculating a regional sediment budget.

Maps showing the distribution of sedimentary environments also provide clues concerning the locations of habitats for bottom dwelling organisms. This is because sea-floor habitats are largely controlled by the kinds of bottom texture and by the strengths of bottom currents. Both of these environmental factors are implicit in the definitions of the three categories of mapped sedimentary environments. Data from this study, therefore, can be used not only to understand the spatial variability of bottom habitats across this entire section of the coast, but also to indicate areas where these habitats might be affected by contaminants deposited with fine-grained sediments. 


\section{CIRCULATION MODELING}

Understanding the circulation of water in Massachusetts and Cape Cod Bays is of critical importance for determining how nutrients, sediment, contaminants and other water-borne materials are transported. Computer circulation models represent a powerful tool to build understanding of transport processes in these bays, as well as for synthesis, scenario testing and prediction. The U.S. Geological Survey has developed a three-dimensional model of circulation in Massachusetts Bay driven by tides, wind, river runoff, surface heating and cooling and remote forcing from the Gulf of Maine. The circulation calculated from this model is used as input to the MWRA's water quality model.

\section{Goals and Achievements}

1. Determine the mechanism for the observed mean counterclockwise circulation in Massachusetts Bay.

* Using the model as a numerical laboratory to isolate the response to specific forcing mechanisms, the Gulf of Maine coastal current was shown to drive southward flow that largely skirts Massachusetts Bay, while the mean circulation in the bay proper was dominated by local wind. Understanding the mean flow is important since it in large part determines how quickly material is flushed from the system.

2. Determine the ability of three-dimensional models to reproduce observed circulation and water properties.

* The currents were simulated over an 18 month period coinciding with the Mass Bays physical oceanography program. Comparing the modeled temperature, salinity and currents to moored observations from 25 instruments, it was shown that the model did a good job of reproducing the seasonal evolution of stratification, and could reproduce the "climate" or statistics of the currents in the bay throughout the year (Fig. 11). This suggests the model is appropriate for studying continuous discharge from sewage outfalls and for modeling the transport during winter storm events.

* The "weather" or individual current events were only reproduced during the winter. This suggests the model is not yet appropriate for modeling specific events during stratified periods, such as reproducing the path of a spring time freshet carrying red-tide organisms from the Gulf of Maine. Ongoing work described below is addressing this issue. 


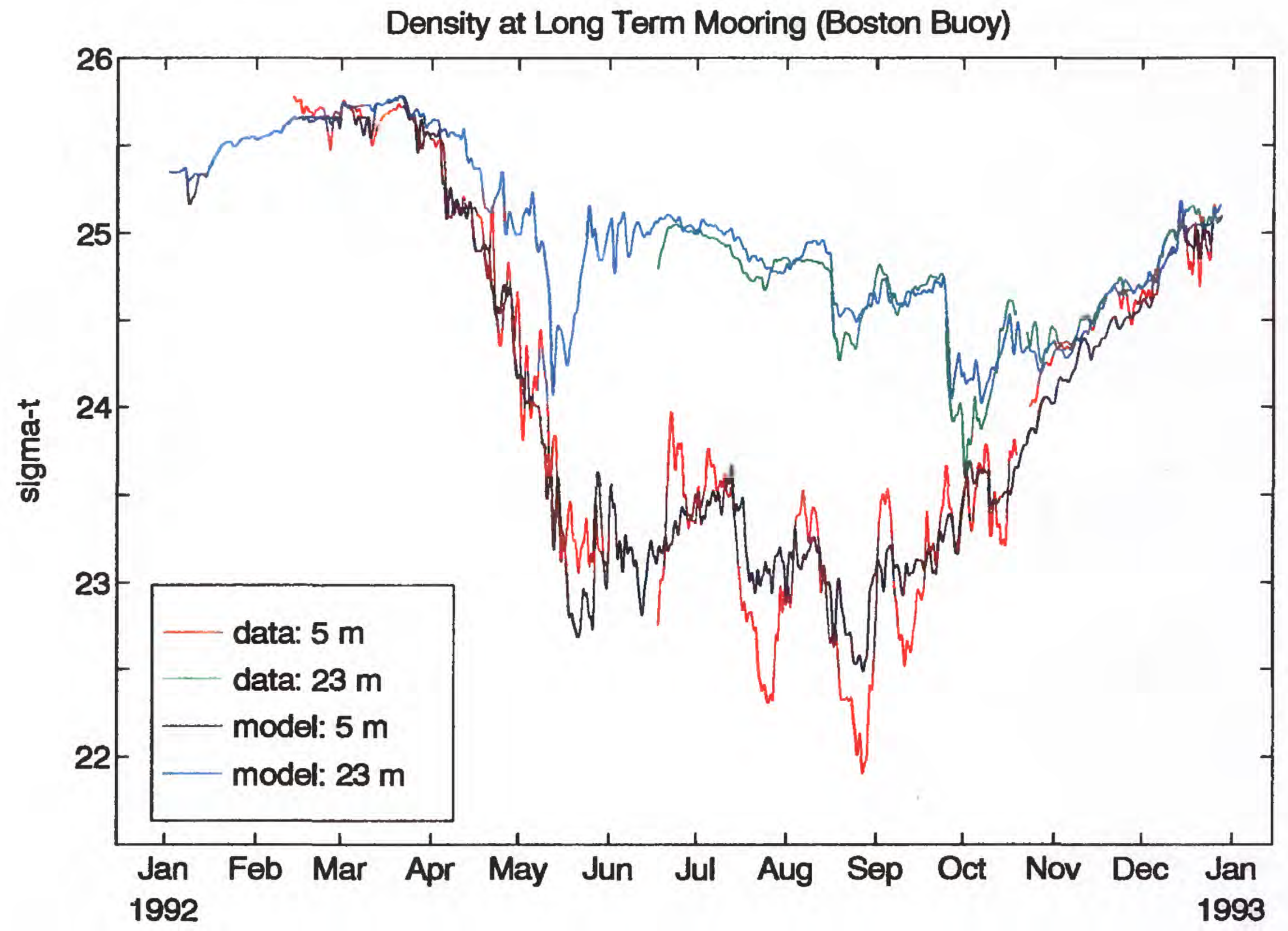

Figure 11. Verification of the 3D hydrodynamic model's ability to reproduce the seasonal density stratification at the future outfall site. Field data is from the USGS mooring (Fig.1). 
3. Determine comparative dilution of effluent due to physical processes from the existing and new outfall sites.

* Comparative dilution simulations for effluent discharged at the existing and new outfall sites were carried out for winter and summer periods. The simulations showed that pollutant concentrations over most of the bays will slightly decrease or remain about the same, while concentrations in Boston Harbor will drop dramatically. A video of these results (Fig. 12) was widely shown at public forums on the potential impact of the new outfall, and was used as evidence by the U.S. Justice Department in a case concerning the effect of the outfall on endangered species on Stellwagen Bank.

4. Provide data for running the water quality model.

* The model is providing input for the water quality model over a three year period from October 1989 to December 1992. We have used high-performance USGS work stations in Reston, Virginia and Woods Hole for this work which would have cost $\$ 800,000$ for CRAY computer time.

\section{Continuing and Future Work}

The USGS is currently using the model in a Regional Marine Research Program funded study of sources, transport and nutrient environment of red tide populations in the western Gulf of Maine. Together with investigators from WHOI and $\mathrm{UNH}$, this work seeks to characterize the physical transport mechanisms that influence the distribution and fate of toxic red tide algae in this region, and the processes by which algae cells are transported to Massachusetts Bay. The ability of the regional model to represent the movement of fresh water from the Kennebec and Androscoggin rivers will be determined.

Over the next three years, the USGS will be developing a regional sediment transport model by interfacing existing surface wave, bottom boundary layer and sediment erosion models into the current hydrodynamic model. Current and suspended sediment data from the long-term mooring (as well as other sites) will be used for calibration and verification.

When the new outfall comes on line, additional hydrodynamic model runs in Massachusetts Bay will be performed to test the ability of the model to simulate the effects of the relocated effluent discharge. 


\section{Dec 1990 16:38}

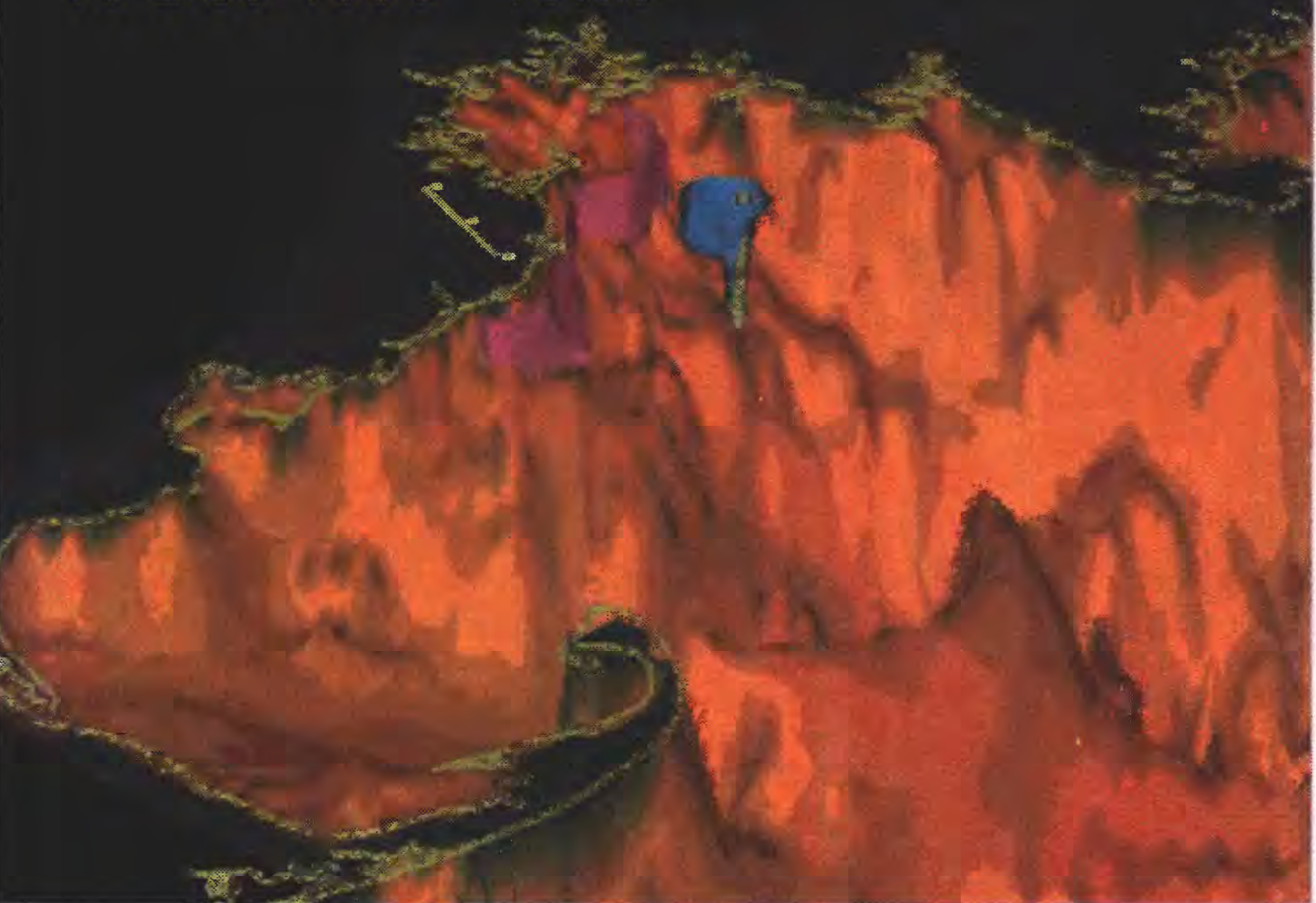

Figure 12. A frame from the video comparing modeled effluent concentrations from the existing and future outfall sites. For a concentration of 1 part effluent to 200 parts seawater (a level at which nutrients introduced at the outfall are diluted to background levels), the region landward of the plume boundary from the present outfall (pink) is much larger than the area enclosed by the boundary of the future outfall plume (boundary shown in blue). This video has been shown widely at public forums and was used as the U.S. Justice Department in the case concerning the effect of the outfall on endangered species on Stellwagen Bank. 


\section{CONTAMINATED-SEDIMENT DATABASE}

Bottom sediments are both a repository for and source of contaminants in estuarine and coastal areas. An integral part of USGS environmental research pertaining to contaminants in marine sediments has been the development of a comprehensive contaminated sediment database for Boston Harbor and Massachusetts Bay. The database contains original data and information about contaminant concentrations in sediment samples and associated sediment properties from the region. The database utilizes existing data to provide a valuable and cost-effective tool for scientists and environmental managers.

\section{Goals and Achievements}

\section{Data Rescue: construct a contaminated sediment database for the Boston} Harbor - Massachusetts Bay region. This entailed utilizing all available sources, published and unpublished. A vast amount of data exists that are valuable for establishing baselines and the ability to compare historic and new conditions in sediments. At the time the work began, in 1991, many experts regarded the goal of accumulating the existing data into an easily utilized database as having doubtful feasibility.

* We demonstrated that it is feasible to build a database which includes data from heterogeneous historical sources and have accumulated more than 2500 samples to date. Fig. 13 is a map that shows the concentrations of lead for surface sediments in the Boston Harbor and western Massachusetts Bay. Maps such as this, and the data in the database, have been used to save MWRA extensive sampling and analysis costs in projects such as the Braintree-Weymouth Relief Facilities Marine Pipeline Feasibility Study.

A comprehensive contaminated sediment data dictionary (definition of all data and documentation fields) was developed that draws on major sediment databases of U.S. Federal and some Canadian agencies and permitted linking of USGS, EPA (Region I), MWRA, Corps of Engineers and other data. This represents the first U.S. attempt at coordinating databases from multiple agencies.

A novel validation system (Fig. 14) was developed to provide users with criteria for identifying whether samples are of a quality useful for their specific purposes, without restricting or losing data. We found and corrected gaps in data documentation, inconsistencies and typographical errors, and anomalous and questionable data in some of the major historical data sets, as well as newer data.

* Previously unusable raw data was made suitable for mapping and evaluation using techniques for converting grain size data, accurately determining latitudes and longitudes from sketch maps, converting formats between database structures, and recording heterogeneous information in ways that allow transfers between most types of computers. 


\section{Lead in Boston Harbor Surface Sediments}

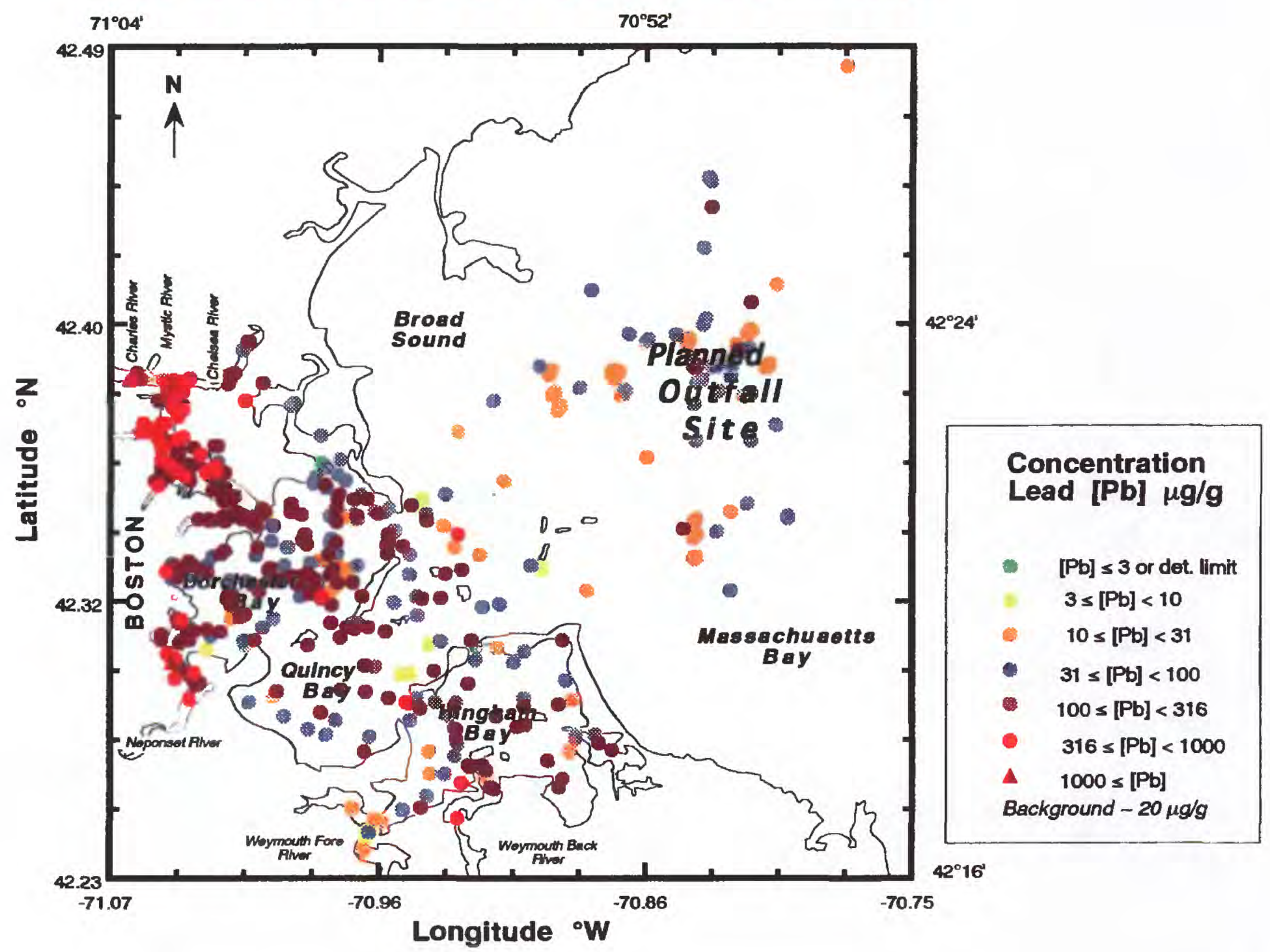

Figure 13. Locations of surface $(0-6 \mathrm{~cm})$ samples and their lead concentrations in Boston Harbor and western Massachusetts Bays sediments. Note the elevated concentrations in the Inner Harbor. Many other metals also show a similar pattern of patchiness with a general trend of values decreasing from the Inner Harbor towards Massachusetts Bay. The locations where contaminant concentrations in sediments are high is a function of both proximity to contaminant source and the presence of fine-grained sediments. 


\section{Boston Harbor metals sorted by descending mercury values}

\begin{tabular}{|c|c|c|c|c|c|c|c|c|}
\hline $\begin{array}{c}\text { Unique } \\
\text { Sample ID }\end{array}$ & Latitude & tude & $\begin{array}{c}C d \\
\mu g / g\end{array}$ & $\begin{array}{c}\mathrm{Cr} \\
\mu \mathrm{g} / \mathrm{g}\end{array}$ & $\begin{array}{c}\mathrm{Cu} \\
\mu \mathrm{g} / \mathrm{g}\end{array}$ & $\begin{array}{c}\mathrm{Hg} \\
\mu \mathrm{g} / \mathrm{g}\end{array}$ & $\begin{array}{c}\mathrm{Pb} \\
\mu \mathrm{g} / \mathrm{g}\end{array}$ & $\begin{array}{l}\mathrm{Zn} \\
\mu \mathrm{g} / \mathrm{g}\end{array}$ \\
\hline & & & .5 & .83 & 80 & 760 & 1200 & 465 \\
\hline & & & 4 & 257 & 64 & 730 & 4.3 & 117 \\
\hline & 0 & & 22.5 & 1.9 & 260 & 3160 & 400 & 29.4 \\
\hline & & & 4 & 1.2 & 200 & 2350 & 505 & 7. \\
\hline $0-1$ & 42. & & 485 & 2.4 & 250 & 1960 & 1100 & 6250 \\
\hline-1 & & & 75 & 1.4 & 47 & 1140 & 450 & 175 \\
\hline-1 & & & 1.1 & 57.8 & 68.8 & 68.8 & 151 & 26 \\
\hline 1 & & & 7.4 & 250 & 460 & 26 & 400 & 80 \\
\hline & & & 3 & 97 & 1650 & 23 & 2000 & 720 \\
\hline & & & 6.2 & 120 & 480 & 20 & 230 & 10 \\
\hline & & & 2.38 & 85.9 & 391 & 18.9 & 108 & 189.42 \\
\hline & & & 2.5 & 136 & 75 & 12 & 77 & 210 \\
\hline & & & 71 & 165 & 83.3 & 10.8 & 142 & 159.28 \\
\hline & & & 1.92 & 73 & 188 & 10.2 & 126 & 143.5 \\
\hline & & & 2.99 & 67.8 & 349 & 9.9 & 87.3 & 151.16 \\
\hline & & & 5.8 & 195 & 218 & 9.4 & 500 & 59 \\
\hline & & & 3 & 302 & 192 & 9.4 & 234 & 24 \\
\hline & & & 3.2 & 240 & 110 & 8 & 143 & 190 \\
\hline & & & 2.8 & 133 & 81 & 6.8 & 84 & 160 \\
\hline & & & 2.8 & 134 & 292 & 6.8 & 84 & 160 \\
\hline & & & 11 & 451 & 338 & 6.8 & 222 & 410 \\
\hline & 42.30722 & -1, & 6.3 & 128 & 108 & 6.7 & 117 & 183 \\
\hline & & & 14 & 653 & 649 & 6.6 & 337 & 583 \\
\hline & & & 7.2 & 250 & 390 & 6.5 & 310 & 950 \\
\hline & & & 8.8 & 418 & 339 & 6.3 & 402 & 50 \\
\hline & & & 4.4 & 292 & 239 & 6.1 & 215 & 31 \\
\hline US00414-1 & 42.33472 & -70.95972 & 4.4 & 255 & 239 & 6.1 & 215 & 317 \\
\hline
\end{tabular}

Figure 14. Data in the Contaminated-Sediment Database undergoes a thorough review for accuracy and quality. A typical working example of use of the VALIDS (Validation by Interactive Data Screening) system is shown here. A data set sorted on mercury values in descending order shows gaps and questionable high values in red. Dark blue denotes unreasonably low values. All questionable metals happened to come from the same laboratory. In a final coding a warning flag might be applied to all metal data from this source. 
2. Expand our understanding of contaminant behavior in bottom sediments. The database, in conjunction with USGS field studies, provides information on contaminant distribution in space and time. This helps in determining sources, fates, transport paths, rates of accumulation of sediments and contaminants, and relations to bottom topography and sediment texture.

* Statistical analysis of the data is useful for determining the degree of heterogeneity and for assessing the effects of contaminant concentrations in the region. Six metals were present in concentrations exceeding available effects-based (animal-toxicity related) screening criteria in over 50 percent of the samples in Boston Harbor (Fig. 15).

* Time trends can be determined by either comparing samples collected at various times in the past or by comparing samples collected down a well-dated core that represent sediments deposited at various times in the past. Our studies from historical data (Fig. 16) indicate that mercury and certain other metals have decreased significantly in surficial sediments in comparison with past measurements. The historical (database) data are important because they involve many more samples than are available from cores and provide a more quantitative measure of change in contaminants with time since they are not subject to mixing of core layers by bottom organisms.

* A comprehensive and annotated bibliography of literature about contaminants in Massachusetts Bay - Boston harbor sediments is being completed in cooperation with The Massachusetts Bays Program.

3. Display and disseminate the data in ways most useful to scientists, resource managers and the general public. The link between contaminant concentrations, toxicity, and sediment environments is now widely accepted; however, it is often difficult to visualize and assimilate the data in ways effective for making resource or environmental policy decisions. The USGS has made practical advances in effective visualization and use of the database.:

* Rectification of the MASSGIS digital coastline and addition of the most detailed Inner Harbor data. This digital coastline can be used on both desktop computers and ARC-INFO.

* New visualization approaches for bathymetry (Fig. 17) and sediment character for desktop computers let scientists, managers and the public "see" bathymetry and sediment character in key areas, along with sampling points in these areas.

* We have provided much data to individual users and participated in advisory panels for a variety of issues needing input on contaminated sediments. The forthcoming CD ROM will provide both practical help to users, as well as a base to build on for the future. 

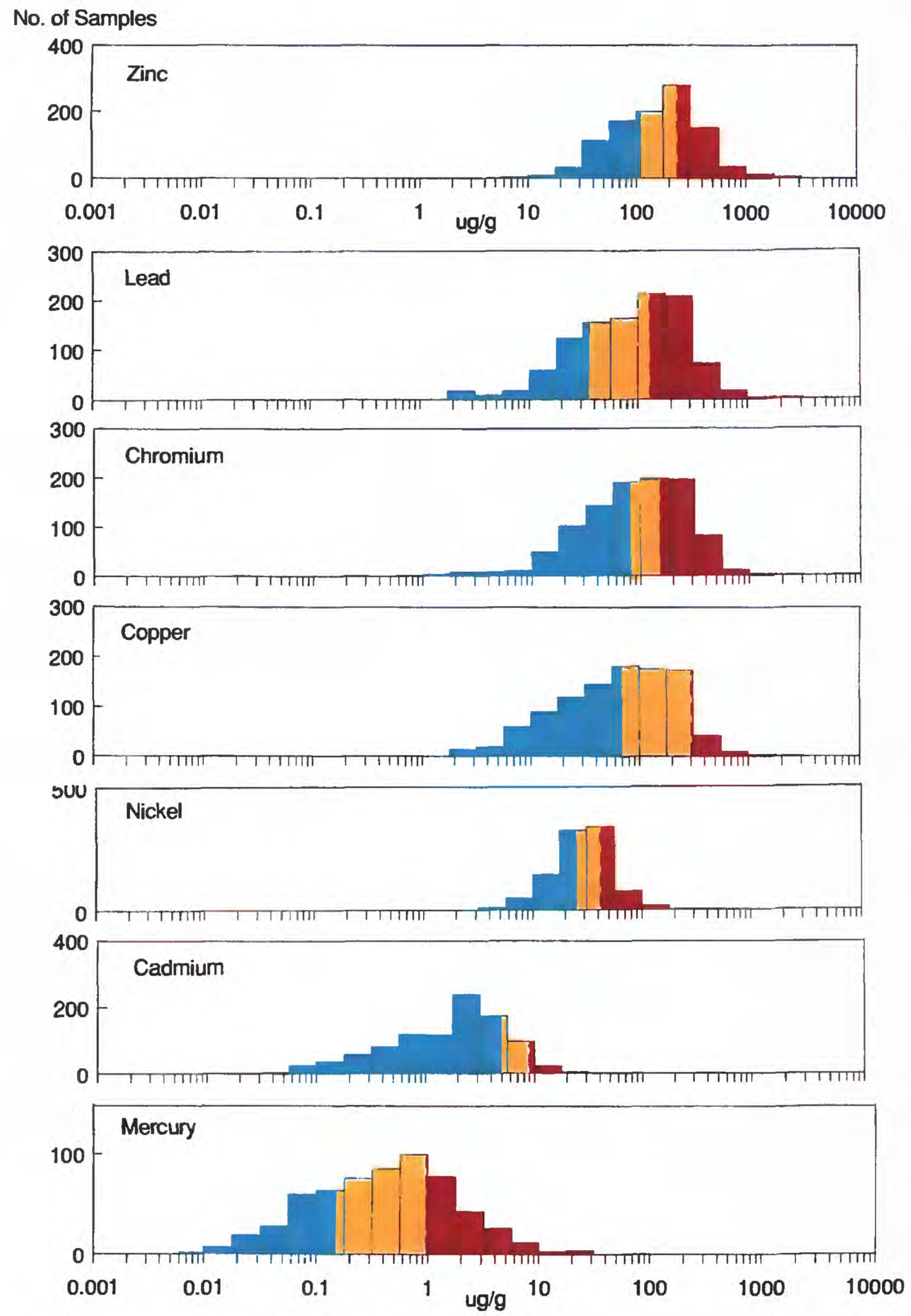

Figure 15. Histograms of partly validated metals data for Boston Harbor sediments show the number of samples and their concentration values. The data are color-coded by toxicity screening levels. ER-L (yellow) and ER-M (red) refer to "effects range" low and medium, respectively (Long and Morgan, 1990). Blue values exhibit no toxic effects. These acute toxicity screening levels were established by determining the lower 10 and 50 percentiles of sample populations for which both bulk chemical concentrations and acute animal toxicity effects data were available. Toxicity criteria derived by MacDonald (1993) have similar values. 


\section{Inner Harbor Surface Sediments (values measured over 20 years)}
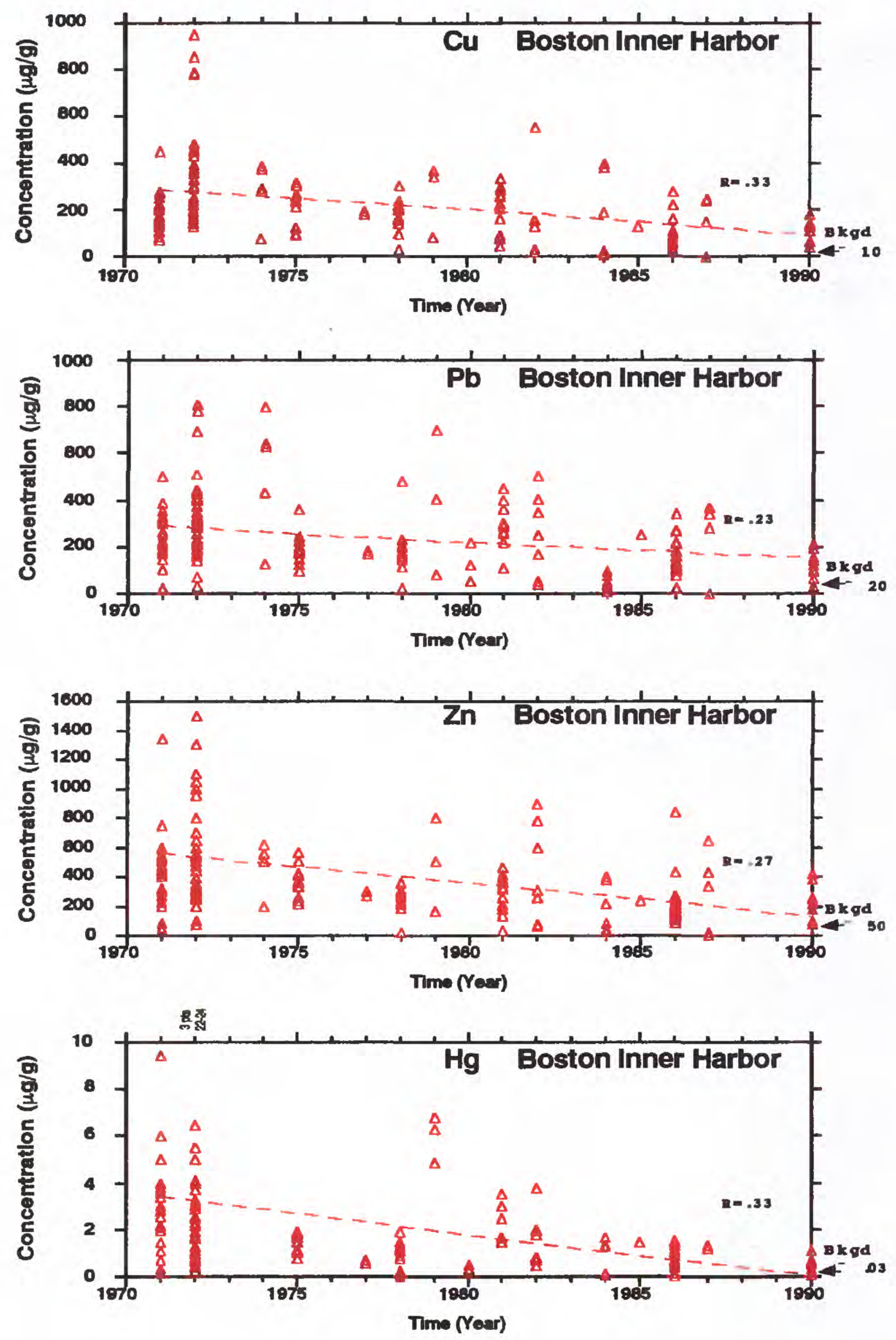

Figure 16. Time-concentration plots for metals in surface sediments from Boston Inner Harbor show up to a factor of two decrease in contaminant concentrations over a 20 year period. The correlation coefficients for each metal are low because of scatter in the data, however, much of the scatter is due to real heterogeneity in the environment, and the trends for all samples (shown here) and for age-class samples are considered significant. 


\section{Boston Harbor Bathymetry}

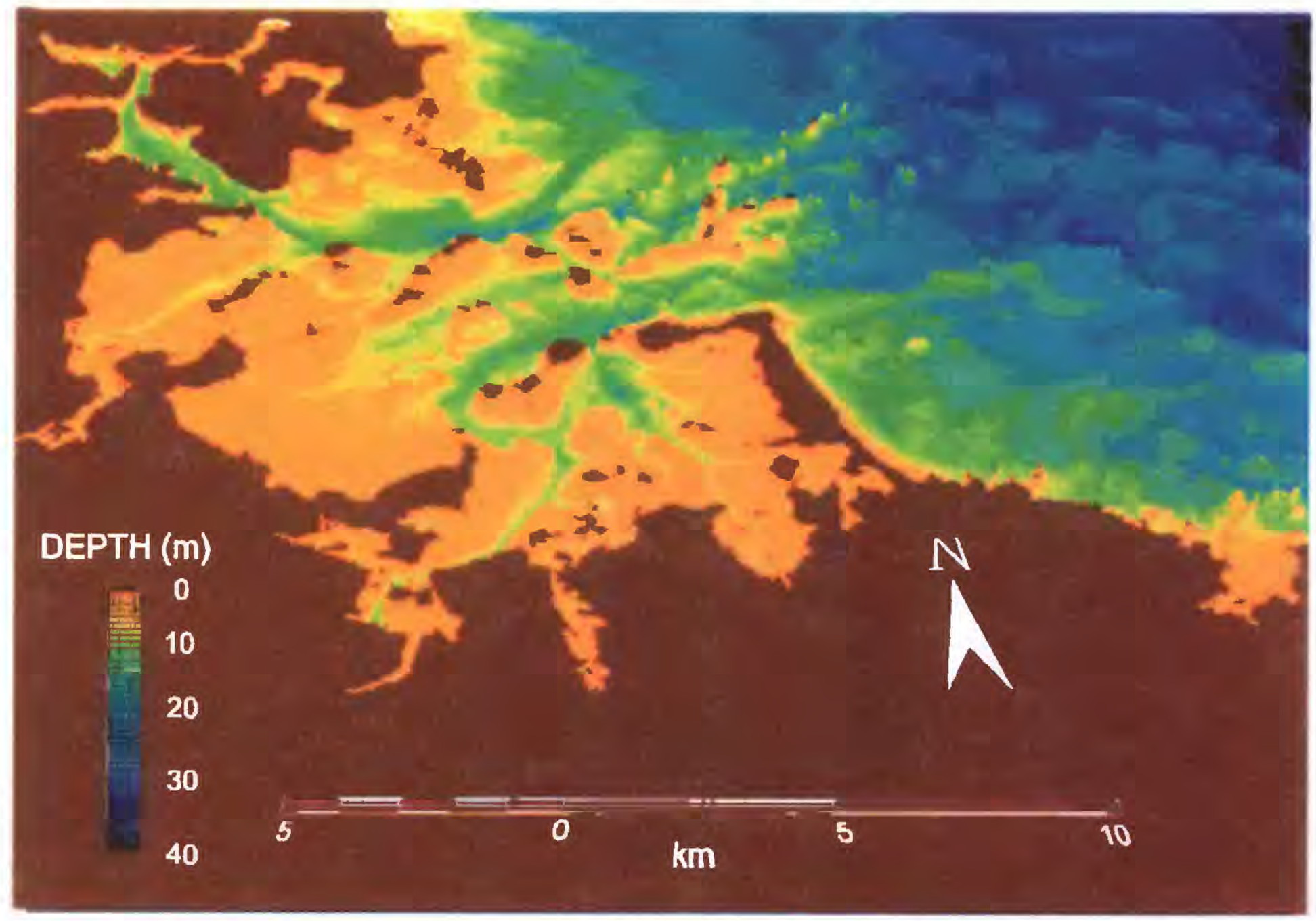

Image prepared on a desktop PC using "TIN" (triangular irregular net) algorithm from NOAA digital bathymetry

Figure 17. An example of color-coded visualization of bathymetry using a rapid triangulation gridding algorithm on a $486 / 50$ IBM compatible desktop computer. 


\section{Continuing and Future Work}

Much effort to date has gone into the labor of searching hundreds of sources and checking the integrity and comparability of data. Addition of more data and database improvement should continue; however, the most exciting aspect of the database is the light that it sheds on problems of identifying contaminant sources, distribution, transport, and fate. Interpretive efforts to date have yielded important information and insights, but only the surface has been scratched in exploiting the data. For example, information on contaminant distributions is required for harbor remediation planning and sediment and contaminant accumulation rates and locations are needed to predict the self-cleaning capacity of the harbor and bay.

\section{Prediction and estimation of contaminant distribution.}

* The database will aid in delimiting "hot spots" requiring higher-tier evaluation and possibly remediation, as well as help define areas and depths of lower-level contamination and "clean" sediments.

\section{Rates of sediment and contaminant accumulation and fluxes.}

* Historical bathymetric data from Corps of Engineers and their contractors' archives can be paired with more recent bathymetric data to establish rates of accumulation of sediment with a reliability comparable to or perhaps greater than radiometric investigations of cores. These data, contaminant information from our database, and other aspects of USGS studies will help determine regional "self-cleaning" rates as well as answer other current and future questions about contaminant fates.

\section{High-resolution mapping and visualization.}

* We can show bottom environments and contaminant distribution more accurately than is done with most currently utilized gridding and contouring systems, which create distortions or artifacts when dealing with complex coastlines, irregular sample distributions and multiple data at single sites. In addition, the visualization tools can be used on desktop computers with little specialized training.

* Our visualization tools allow sediment data to be linked to toxicity and monitoring studies involving fish, shellfish, and other bottom-living organisms. Monitoring stations can then be placed with improved cost-effectiveness and reliability. Boston Harbor could well become the national leader among coastal areas in making monitoring more meaningful.

\section{Bibliography of contaminant data.}

* Publication of the current bibliography will help bring user communities together, and should stimulate preparation of more complete work in the future. It should also catalyze cooperative agreement on storage of key documents and citation of the locations where detailed reference material can be obtained or used. 


\section{REFERENCES CITED IN THIS SUMMARY}

Blumberg, A.F., R.P. Signell and H.L. Jenter, 1993, Modeling transport processes in the coastal ocean, Journal of Environmental Engineering, v. 1, p. 31-52.

Keay, K., M. Mickelson, and D. Shea, 1993, Loading to and distribution of the sewage indicator Clostridium perfringens in sediments of Boston Harbor and the Massachusetts Bays. GSA Abstracts with Programs, V. 25, no. 6, p. A-127.

Long, E.R., and L.G. Morgan, 1990, The potential for biological effects of sedimentsorbed contaminants tested in the National Status and Trends Program. NOAA Technical Memorandum, NOS/OMA-52. Seattle, WA: Ocean Assessments Division, NOS/NOAA, 175p. + appendices.

MacDonald, D.E., 1993, Development of an approach to the assessment of sediment quality in Florida coastal waters. Report prepared for the Florida Department of Environmental Protection, Tallahassee, FL, 133p.

Signell, R.P., H.L. Jenter and A.F. Blumberg, 1994, Modeling the seasonal circulation in Massachusetts Bay. In Estuarine and Coastal Modeling, Proceedings of the 3rd International Conference, edited by M. L. Spaulding, American Society of Civil Engineers, New York. p.578-590. 
Publications resulting from the MWRA-USGS Joint Funding Agreements and related USGS programs in Boston Harbor and Massachusetts Bay.

Scientific Papers and reports:

Blumberg, A.F., R.P. Signell and H.L. Jenter, 1993, Modeling transport processes in the coastal ocean, Journal of Environmental Engineering, v. 1, p. 31-52.

Bothner, M.H., C.M. Parmenter, D.C. Twichell, C.F. Polloni, and H.J. Knebel, 1992, A geologic map of the sea floor in western Massachusetts Bay, constructed from digital sidescan sonar images, photography, and sediment samples, USGS Digital Data Series, DDS-3.

Bothner, M.H., M. Buchholtz ten Brink, C.M. Parmenter, W.M. d'Angelo, and M.W. Doughten, 1993, The distribution of silver and other metals in sediments from Massachusetts and Cape Cod Bays: U.S. Geological Survey Open-File report 93-725. $31 \mathrm{p}$.

Bothner, M.H., R.P. Signell, and B. Butman, 1993, Boston Harbor and Massachusetts Bay. U.S. Geological Survey Yearbook, Fiscal Year 1993, p.17-19.

Bothner, M.H., and M. Buchholtz ten Brink, 1994, The distribution of silver in sediments from Massachusetts and Cape Cod Bays, and the changes in concentration with time - preliminary analysis. Proceedings of a meeting, "MWRA Benthic and Sediment Science Review", Battelle Ocean Sciences, Duxbury Mass., April 28, 1994. $22 p$.

Bothner, M.H., M. Buchholtz ten Brink, and G.E. Ravizza, 199X, Silver and other tracers of sewage particles in coastal and deep sea sediments off the east coast, USA. Proceedings of the Second International Conference on Transport, Fate and Effects of Silver in the Environment, University of Wisconsin-Madison, September 11-14, 1994, in press.

Bothner, M.H., M. Buchholtz ten Brink, B. Butman, H.J. Knebel, F.T. Manheim, and R.P. Signell, 1994, Circulation and contaminant transport in Massachusetts coastal waters: Achievements and future plans. U.S. Geological Survey Open File Report 94649, (this document).

Buchholtz ten Brink, M., F.T. Manheim, and J.C. Hathaway, 1993, Report to the U.S. Army Corps of Engineers, New England District, on incorporation of COE data into the contaminated sediment database. Feb. 1993, Administrative Report.

Buchholtz ten Brink, M. R., F.T. Manheim, N.K. Soderberg, and J.C. Hathaway, 1993, Data and Information Management at the Branch of Atlantic Marine Geology and the Contaminated-Sediment Database. Workshop proceedings, Gulf of Maine Data and Information Management, Durham N.H., Nov. 2-3, 1993. p. 80-106. 
Butman, B., M.H. Bothner, J.C. Hathaway, H.L. Jenter, H.J. Knebel, F.T. Manheim, and R.P. Signell, 1992, Contaminant transport and accumulation in Massachusetts Bay and Boston Harbor: a summary of U.S. Geological Survey studies: U.S. Geological Survey Open-file Report 92-202, 42 p.

Geyer, W. R. and R. P. Signell, 1992, A reassessment of the role of tidal dispersion in estuaries, Estuaries, v. 15, no. 2, p. 97-108.

Geyer, W. R., G. B. Gardner, W. S. Brown, J. Irish, B. Butman, T. Loder, and R. P. Signell, 1992, Final Report: Physical oceanographic investigation of Massachusetts and Cape Cod Bays: Boston, Massachusetts Bays Program, 497p.

Hathaway, J.C., 1992, List of References and Parameter Codes Boston Harbor Data Management File. U.S. Geological Survey Open File Report 92-304.

Hotchkiss, F. S., and R.P. Signell, 1991, Average near-bottom currents in Massachusetts Bay and Cape Cod Bay measured with Woodhead drifters: Progress Report for drifters released Sept. 1990 through May 1991. U.S. Geological Survey Open-File Report 91-361, 14 p.

Hotchkiss, F., W. Strahle, M. Martini, and B. Butman, 1993, Long-term Oceanographic Observations in Western Massachusetts Bay: Data Report for December 1989 to February 1992: Open File Report 93-710, 115 p.

Irish, J.D. and R.P. Signell, 1992, Tides of Massachusetts and Cape Cod Bays, Woods Hole Oceanographic Institution Tech. Report WHOI-92-35, $62 \mathrm{p}$.

Jenter, H.L. and R.P. Signell, 1992, Unidata's NetCDF: A Public-Domain Solution to Data-Access Problems for Numerical Modelers. in Estuarine and Coastal Modeling, Proceedings of the 2nd International Conference, edited by M. L. Spaulding, American Society of Civil Engineers, New York. p. 72-82.

Jenter, H.L, R.P. Signell and A.F. Blumberg, 1993, Modeling the Tides of Massachusetts and Cape Cod Bays, in Proceedings of the 1993 ASCE Hydraulic Engineering Conference, San Francisco, CA. p. 2,323-2,332.

Jenter, H.L., R. P. Signell and A.F. Blumberg, 1994, Modeling Outfall Plume Dynamics in Massachusetts Bay. Submitted.

Knebel, H.J., R.R. Rendigs, and M.H. Bothner, 1991, Modern sedimentary environments in Boston Harbor, Massachusetts: Journal of Sedimentary Petrology, v. 61 , no. 5 , p. $791-804$.

Knebel, H.J., R.R. Rendigs, R.N. Oldale, and M.H. Bothner, 1993, Sedimentary framework of Boston Harbor, Massachusetts, in C.H. Fletcher, III, and J.F. Wehmiller, eds., Quaternary Coasts of the United States: Marine and Lacustrine Systems: Society for Sedimentary Geology (SEPM) Special Publication 48, p. 35-43. 
Knebel, H.J., 1993, Sedimentary environments within a glaciated estuarine-inner shelf system: Boston Harbor and Massachusetts Bay: Marine Geology v. 100, p. 7-30.

Knebel, H.J., and R.C. Circe', 1994, Seafloor environments within the Boston Harbor-Massachusetts Bay sedimentary system: a regional synthesis: Journal of Coastal Research, v. 10, no. 48 manuscript pages (in press).

Knebel, H.J., 1995, Seafloor characterization in Boston Harbor and Massachusetts Bay: Proceedings of the 1993 Exclusive Economic Zone Symposium on Mapping and Research, U.S. Geological Survey Circular, 20 manuscript pages (in press).

Knebel, H.J., and R.C. Circe', 1995, Maps and diagrams showing the acoustic and textural characteristics and distribution of bottom sedimentary environments, Boston Harbor and Massachusetts Bay: U.S. Geological Survey Miscellaneous Field Studies Map, 2 sheets, (in press).

Manheim, F.T., and J.C. Hathaway, 1991, Polluted sediments in Boston HarborMassachusetts Bay: progress report on the Boston Harbor data Management File. U.S. Geological Survey Open File Report 91-331, 27 p.

Martini, M. and W. Strahle, 1993, Multi-Parameter Intelligent Data Acquisition System (MIDAS): Hardware Documentation. U.S. Geological Survey Open File Report 93-721.

Martini, M. and A. Williams, III, 1993, Benthic Acoustic Stress Sensor (BASS): Electronics Check-Out Procedures. U.S. Geological Survey Open File Report 93-722.

Oldale, R. N., 1993-1994, Geologic Origins of Stellwagen Bank, The Cape Naturalist, Journal of the Cape Cod Museum of Natural History, Brewster, MA, p. 27-31.

Oldale, R. N., 1994, The geology of Stellwagen Bank, U.S. Geological Survey Open File Report 94-xxx, 17 p.

Oldale, R.N., H.J. Knebel, and M.H. Bothner, 1994, Submerged and eroded drumlins off northeastern Massachusetts. Geomorphology 9, p. 301-309.

Parmenter, C.M., and M.H. Bothner, 1993, The distribution of Clostridium perfringens, a sewage indicator, in sediments of coastal Massachusetts. U.S. Geological Survey Open File Report 93-8, 45p.

Poppe, L.J., and A.M. Moffett, 1993, Ground water discharge and the related nutrient and trace metal fluxes into Quincy Bay, Massachusetts. Environmental Monitoring and Assessment v. 25, p. 15-27.

Rendigs, R.R., and R.N. Oldale, 1990, Maps showing the results of a subbottom acoustic survey of Boston Harbor, Massachusetts: U.S. Geological Survey Miscellaneous Field Studies Map MF 2124, 2 sheets. 
Rendigs, R.R. and R.N. Oldale, 1993, The Quaternary Stratigraphy of Boston Harbor. Geological Society of America Guidebook October 1993. v. 2, pp U11-U14.

Signell, R.P., H.L. Jenter and A.F. Blumberg, 1994, Modeling the seasonal circulation in Massachusetts Bay. In Estuarine and Coastal Modeling, Proceedings of the 3rd International Conference, edited by M. L. Spaulding, American Society of Civil Engineers, New York. p.578-590.

Signell, R.P, 1992, Tide- and wind-driven flushing of Boston Harbor. In Estuarine and Coastal Modeling, Proceedings of the 2nd International Conference, edited by M. L. Spaulding, American Society of Civil Engineers, New York. p. 595-606.

Signell, R.P and B. Butman, 1992, Modeling tidal exchange and dispersion in Boston Harbor. Journal of Geophysical Research, v. 97, no. C10, p. 15,591-16,606.

Signell, R.P. and E.L. Wright, 1993, Circulation and Plume Tracking in Massachusetts Bay, in Proceedings of the 2nd Annual International AVS Conference, Lake Buena Vista, Florida. v. 1, paper 41, p. 74-86.

Strahle, W.J., Perez, C.L., Martini, M.A. Antifouling, 1994, Leaching Technique for Optical Lenses. Proc. of OCEANS '94 conf., v. II, p. 710-715.

\section{Abstracts of presentations:}

Bogden, P., P. Rizolli and R.P. Signell, 1994, Open ocean boundary conditions from interior data: Local and remote forcing of Massachusetts Bay, EOS, Transactions, American Geophysical Union, v. 75, no. 3, p. 80.

Bothner, M.H., C.M. Parmenter, D.C. Twichell, C.F. Polloni, and H.J. Knebel, 1992, Sea floor maps of the proposed sewage outfall site in massachusetts bay: computer display using a CD-ROM. Proceedings of the Seventh Annual Boston Harbor/Massachusetts Bays Symposium, edited by R. Stern, Mass. Bay Marine Studies Consortium, PO Box 660, Boston, MA 02125-0005, February 10-11, 1992.

Bothner, M.H., and M. Buchholtz ten Brink, 1994, The distribution of silver in sediments of Massachusetts and Cape Cod Bays. Proceedings of the Ninth Annual Boston Harbor/Massachusetts Bay Symposium: Kennedy Library, Boston Massachusetts, March 24-25, 1994. Convener: Stern R., Mass. Bay Marine Studies Consortium, PO Box 660, Boston, MA 02125-0005.

Bothner, M., R.P. Signell, C. Parmenter, R. Rendigs, B. Butman, 1993, The Influence of Storms on Sediment Resuspension in Western Massachusetts Bay: Implications for Pollutant Transport. GSA, Abstracts of Programs v. 25, Number 6, Page 127.

Brown, W.S., B. Butman, G.B. Gardner, W.R. Geyer, J.D. Irish, N. Pettigrew, and R.P. Signell, 1992, The Physical Oceanography of Massachusetts Bay. Proceedings of the 
Seventh Annual Boston Harbor/Massachusetts Bay Symposium, edited by R. Stern, Mass. Bay Marine Studies Consortium, PO Box 660, Boston, MA 02125-0005, February 10-11, 1992.

Buchholtz ten Brink, M., F.T. Manheim, J.C. Hathaway, S. Aach, T.J. Fredette, D. Hermann, and W. Mah, 1993, Development of a more comprehensive contaminated sediment database for Boston Harbor - Massachusetts Bay - Cooperation between US Geological Survey and New England Division of the U.S. Army Corps of Engineers, 8th Annual Boston Harbor/Massachusetts Bays Symposium, May 1993.

Buchholtz ten Brink, M., B. Butman, M. Bothner, F.T. Manheim, H.J. Knebel, J.C. Hathaway, R.P. Signell and P.C. Valentine, 1994, Contaminant distribution and transport in Boston Harbor and Massachusetts Bay, Geological Association of Canada Annual Meeting May 16-18, 1994, Waterloo, Canada.

Buchholtz ten Brink, M., F.T. Manheim, J.C. Hathaway, and M.H. Bothner, 1994, Contaminant metal concentrations in sediments of Boston Harbor, Massachusetts Bay and Cape Cod Bay, Proceedings of the Ninth Annual Boston Harbor/Massachusetts Bay Symposium: Kennedy Library, Boston Massachusetts, March 24-25, 1994. Convener: Stern R., Mass. Bay Marine Studies Consortium, PO Box 660, Boston, MA 02125-0005.

Butman, B., R.P. Signell and W. R. Geyer, 1992, Examples of major transport events in the Massachusetts Bays during 1990 Part II: Wind-driven currents. Proceedings of the Seventh Annual Boston Harbor/Massachusetts Bay Symposium, edited by R. Stern, Mass. Bay Marine Studies Consortium, PO Box 660, Boston, MA 02125-0005, February 10-11, 1992.

Butman, B., M.H. Bothner, J.C. Hathaway, H.J. Knebel, F.T. Manheim, R.P. Signell, and M. ten Brink, 1993, Contaminant transport and accumulation in Boston Harbor and Massachusetts Bay: Geological Society of America Annual Meeting, Abstracts with Program, v. 25, p. 289.

Butman, B., M.H. Bothner, J.C. Hathaway, H.J. Knebel, F.T. Manheim, R.P. Signell, and M. Buchholtz ten Brink, 1993, USGS studies on the composition, distribution, and transport of contaminated sediments in Massachusetts Bay (abs.): Proceedings, Conference on the Remediation of Sediments, Rutgers--The State University of New Jersey.

Butman, B., and F.T. Manheim, 1993, (conveners), A crisis in waste management, economic vitality, and a coastal marine environment, Boston Harbor and Massachusetts Bay: 2nd Annual Environmental Forum, cosponsored by GSA Geology and Public Policy Committee and Environmental Studies Institute, Geological Society of America Annual Meeting, Oct. 25, 1993.

Geyer, W.R., B. Butman and R.P. Signell, 1992, Examples of major transport events in the Massachusetts Bays during 1990 Part I: Freshwater Inputs. Proceedings of the 
Seventh Annual Boston Harbor/Massachusetts Bay Symposium, edited by R. Stern, Mass. Bay Marine Studies Consortium, PO Box 660, Boston, MA 02125-0005, February 10-11, 1992.

Hathaway, J.C., F.T. Manheim, L.D. North, J.M. Cahill, K.M. Imbalzano, and M. Liebman, 1992, A comprehensive sediment database for Boston Harbor and Massachusetts Bay. Proceedings of the Seventh Annual Boston Harbor/Massachusetts Bays Symposium, edited by R. Stern, Mass. Bay Marine Studies Consortium, PO Box 660, Boston, MA 02125-0005, February 10-11, 1992.

Hathaway, J.C., M. Buchholtz ten Brink, F.T. Manheim, and M.H. Bothner, 1994, Contaminated sediments in Boston Harbor and Massachusetts Bay: Spatial and Temporal Trends, 1994 Ocean Sciences Meeting: EOS, Transactions, American Geophysical Union, v. 75:3, p. 144.

Hathaway, J.C., M. Buchholtz ten Brink, F.T. Manheim, and M.H. Bothner, A legacy of contaminated sediments in Boston Harbor. Geological Society of America, Abstracts with Programs, v. 25, no.8, p. A-126.

Hotchkiss, F. S., 1992, Estimating net near-bottom currents by using seabed drifters in Massachusetts and Cape Cod Bays: Proceedings of the Seventh Annual Boston Harbor/Massachusetts Bays Symposium, edited by R. Stern, Mass. Bay Marine Studies Consortium, PO Box 660, Boston, MA 02125-0005, February 10-11, 1992.

Hotchkiss, F. S., 1994, Seabed Drifters Suggest Seasonal Changes in Bottom Currents in Massachusetts and Cape Cod Bays, High Dispersion in Stellwagen Basin, Proceedings of the Ninth Annual Boston Harbor/ Massachusetts Bays Symposium, edited by R. Stern, Mass. Bay Marine Studies Consortium, PO Box 660, Boston, MA 02125-0005, March 24-24, 1994.

Knebel, H.J., R.R. Rendigs, and M.H. Bothner, 1989, Modern sedimentary environments in Boston Harbor: Geological Society of America, Abstracts with Programs, v. 21, no. 6, p. A330.

Knebel, H.J., R.R. Rendigs, R.N. Oldale, and M.H. Bothner, 1991, Sedimentary framework of Boston Harbor, Massachusetts: Geological Society of America, Abstracts with Programs, v. 23, no. 1, p.54.

Knebel, H.J., C.M. Parmenter, and M.H. Bothner, 1991, Sedimentary environments within an estuarine-inner shelf system: Boston Harbor and Massachusetts Bay: Geological Society of America, Abstracts with Programs, v. 23, no. 5, p. A384-A385.

Knebel, H.J., C.M. Parmenter, and M.H. Bothner, 1992, Sedimentary environments within an estuarine-inner shelf system: Boston Harbor and Massachusetts Bay. Proceedings of the Seventh Annual Boston Harbor/Massachusetts Bays Symposium, edited by R. Stern, Mass. Bay Marine Studies Consortium, PO Box 660, Boston, MA 02125-0005, February 10-11, 1992. 
Knebel, H.J. 1993. Seafloor sedimentary environments in Boston Harbor and Massachusetts Bay: A regional synthesis. Proceedings of the Eighth Annual Boston Harbor/Massachusetts Bay Symposium, edited by R. Stern, Mass. Bay Marine Studies Consortium, PO Box 660, Boston, MA 02125-0005, March 31 - April 1, 1993.

Knebel, H.J., and R.C. Circe', 1993, Bottom processes within the Boston HarborMassachusetts Bay sedimentary system: Implications for contaminant transport, accumulation, and monitoring (abs.): Geological Society of America, Abstracts with Programs, v. 25, no. 6, p. A-126.

Knebel, H.J., 1993, Seafloor characterization in Boston Harbor and Massachusetts Bay. Abstracts, 1993 Exclusive Economic Zone Symposium, p. 14.

Manheim, F.T., J.C. Hathaway, and M.R. Buchholtz ten Brink, 1992, Contaminated sediment distribution and transport in sediments of Boston Harbor and Massachusetts Bay. EOS, Transactions, American Geophysical Union, v. 73, no. 14, p. 164.

Manheim, F.T., J.C. Hathaway, and M.R. Buchholtz ten Brink, 1992, Compiling sediment and pollutant databases from the historical record: results of pilot studies from the Boston. Harbor Massachusetts Bay Program. Presented at the U.S. Environmental Protection Agency Conference on Polluted Sediment, April 21-23, Chicago.

Manheim, F.T., J.C. Hathaway, and M.R. Buchholtz ten Brink, 1992, Boston Harbor-Massachusetts Bay, a case study for distribution of metals in contaminated sediments. 29th International Geological Congress, Abstracts v. 3, p. 894.

Manheim, F.T., J.C. Hathaway, M. Buchholtz ten Brink, and M.H.Bothner, 1993, Contaminant concentrations in sediments of Boston Harbor-Massachusetts Bay: Distribution with time, location and physical properties of sediments. Presented at the Eighth Annual Boston Harbor/Massachusetts Bays Symposium, May 1993, Boston.

Manheim, F.T., M.R. Buchholtz ten Brink, and J.C. Hathaway, 1993, Data on chemical composition of contaminated sediments in coastal-estuarine areas of the U.S.: Recent developments and scientific and management potentials. Geological Society of America Abstracts with Program, 25, 288. Boston, MA. Oct. 25-28, 1993.

Manheim, F.T., J.C. Hathaway, and M.R. Buchholtz ten Brink, 1992, Building contaminated sediment databases in impacted coastal waters: the Boston-Harbor Massachusetts Bay Case. International conference on Contaminated Aquatic sediments: Historical Records, Environmental Impact, and Remediation, June 14-16, 1993, Milwaukee. Program with abstracts.

Parmenter, C.M. and M.H. Bothner, 1993, The distribution of Clostridium perfringens, a sewage indicator, in suspended matter and bottom sediments of coastal 
Massachusetts. Geological Society of America, Abstracts with Programs, v. 25, no.6, p. A-128.

Poppe, L.J. and A.M. Moffett, 1992, Measurements of groundwater seepage and the related nutrient and trace metal fluxes into Quincy Bay, Massachusetts. Proceedings of the Seventh Annual Boston Harbor/Massachusetts Bays Symposium, edited by R. Stern, Mass. Bay Marine Studies Consortium, PO Box 660, Boston, MA 02125-0005, February 10-11, 1992.

Rendigs, R.R., R.N. Oldale, R.N., 1990, Geologic investigation of Boston Harbor, MA: Mass Bay Symposium, Mass Bay Marine Studies Consortium, Boston Jan 1990, 5th Annual Boston Harbor/Massachusetts Bay Symposium, p. 13.

Signell, R.P., H.L. Jenter, and A.F. Blumberg, 1992, A three-dimensional circulation model of Massachusetts Bay. Proceedings of the Seventh Annual Boston Harbor/Massachusetts Bays Symposium, edited by R. Stern, Mass. Bay Marine Studies Consortium, PO Box 660, Boston, MA 02125-0005, February 10-11, 1992.

Signell, R.P., H.L. Jenter and A.F. Blumberg, 1992, Modeling the mean flow in Massachusetts Bay, EOS, Transactions, American Geophysical Union, v. 73, no. 43, p. 298.

Signell, R.P. and E.E. Adams, 1993, Predicting the fate of the outfall discharge, 2nd Annual Environmental Forum, GSA, Boston MA. Abstracts with Programs v. 25, Number 6, p. 26.

Signell, R.P. and B. Butman, 1993, Circulation in Boston Harbor and Massachusetts Bay, GSA, Abstracts with Programs v. 25, Number 6, p. 126.

Signell, R.P. and E.L. Wright, 1993, Circulation and plume tracking in Massachusetts Bay, in Proceedings of the 2nd Annual International AVS Conference, Lake Buena Vista, Florida.

Signell, R.P., H.J. Jenter, and A.F. Blumberg, 1993, Modeling the seasonal circulation in Massachusetts Bay. Proceedings of the Eighth Annual Boston Harbor / Massachusetts Bay Symposium, edited by R. Stern, Mass. Bay Marine Studies Consortium, PO Box 660, Boston, MA 02125-0005, March 31 -April 1, 1993.

Signell, R.P. and B. Butman, 1994. Modeling the storm response in western Massachusetts Bay, EOS, Transactions, American Geophysical Union, v. 75, no. 3, p. 80. 